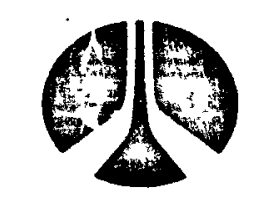

Rockwell International

\section{Atomics International Division \\ Rockwell Hanford Operations \\ Richland, WA 99352}

\title{
ASSESSMENT OF HANFORD BURIAL GROUNDS \\ AND INTERIM TRU STORAGE
}

\section{MASTER}

\section{NOTICE}

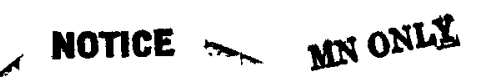

PORTIONS OF THIS REPORT ARE ILLEGIBIE. It

has been reproduced from the best avaliable copy to permit the broadest possible avalk ability.

This Report was prepared as an account of work sponsored by the United States Government. Neither the United States nor the United States Department of Energy, nor any of their Employees, nor any of their Contractors, Subcontractors, or their Employees, makes any warranty, express or implied, or assumes any legal liability or responsibility for the accuracy, completeness, or usefulness of any information, apparatus, product or process disclosed, or represents that its use would not infringe privately owned rights.

J. F. Geiger

Engineering Department

Production and Waste Management Division

\author{
D. J. Brown \\ R. E. Isaacson \\ Research Department \\ Research and Engineering Division
}

August 1977

This neport was preped as an account of work sponsored by the United Statea Govemment. Netther the United States nor the United States Department of Energy, nor any of their employees, nor any of their contractors, subcontractors, or their employees, makes any warranty, express or umplied, or assumes any legal liability or responsibility for the accuracy, completenes or usefulness of any information, apparatus, product or process disclosed, or fipresents that its uee would not inf ringe privately owned rights.

Operated for the Energy Research and Development Administration by Rockwell Hanford Operations under Contract EY-77-C-06-1030

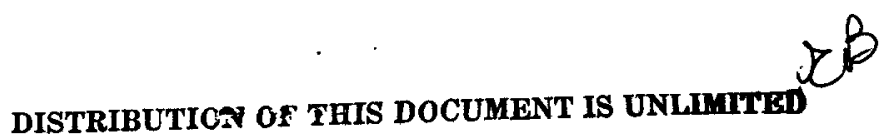




\section{DISCLAIMER}

This report was prepared as an account of work sponsored by an agency of the United States Government. Neither the United States Government nor any agency Thereof, nor any of their employees, makes any warranty, express or implied, or assumes any legal liability or responsibility for the accuracy, completeness, or usefulness of any information, apparatus, product, or process disclosed, or represents that its use would not infringe privately owned rights. Reference herein to any specific commercial product, process, or service by trade name, trademark, manufacturer, or otherwise does not necessarily constitute or imply its endorsement, recommendation, or favoring by the United States Government or any agency thereof. The views and opinions of authors expressed herein do not necessarily state or reflect those of the United States Government or any agency thereof. 


\section{DISCLAIMER}

Portions of this document may be illegible in electronic image products. Images are produced from the best available original document. 


\section{TABLE OF CONTENTS}

PAGE

ABSTRACT

INTRODUCTION 2

SUMMARY ASSESSMENT AND CONCLUSIONS

THE HANFORD ENVIRONMENT

FACILITIES AND OPERATING PRACTICES

THE HANFORD ENVIRONMENT 9

GENERAL DESCRIPTION AND INFROMATION 9 ECOLOGY

HANFORD SOLID WASTE BURIAL GROUNDS 26

BURIAL SITES AND HISTORY $\quad 26$

INVENTORIES AND CURRENT RECEIPTS 26

FACILITIES AND PRACTICES $\quad 44$

TRU WASTE RETRIEVABLE STORAGE

NONTRU BURIAL

WASTE PROCESSING

SUPPORT FACILITIES AND SERVICES

PERSONNEL $\quad 59$

EMERGENCY PLANNING $\quad 60$

$\begin{array}{ll}\text { RECORDS } & 60\end{array}$

PLANNED STUDIES AND ACTIVITIES . . 62

MONITORING AND CONTROL OF RADIOACTIVITY 62

OPERATIONAL NEEDS AND IMPROVEMENTS

REFERENCES $\quad 69$ 


\section{LIST OF TABLES}

Page

I. Solid Radioactive Waste Storage and Burial Sites, 100 Areas 38

II. Solid Waste Burial Site Inventories, 100 Areas 39

III. Solid Radioactive Waste Storage and Burial Sites, 200 East 40

IV. Solid Radioactive Waste Storage and Burial Sites, 200 West 41

V. Solid Radioactive Waste Storage and Burial Sites, 300-600 Areas 42

VI. Storage and Burial Quantities FY 1976 


\section{LIST OF FIGURES}

Page

I. Geography of the Hanford Reservation

II. Sedimentary Rocks Overlaying the Columbia River Basalt in the Pasco Basin

III. General Structure of the Yakima Basalts in the Pasco Basin

IV. Block Diagrams Depicting Possible Sequence of Events in Pasco Basin Near Close of Ice Age

V. Depositional Features Related to Past and Present Wind Erosion

VI. Hydrology of Hanford Reservation

VII. Hanford Soil Moisture Content

VIII. Biota Existing on the Hanford Reservation

IX. $100 \mathrm{~B}$ and C Area Solid Radioactive Waste Disposal Sites 27

$X$. $100 \mathrm{D}$ and DR Area Solid Radioactive Waste Disposal Sites 28

XI. $100 \mathrm{~F}$ Area Solid Radioactive Waste Disposal Sites 29

XII. $100 \mathrm{H}$ Area Solid Radioactive Waste Disposal Sites 30

XIII. $100 \mathrm{~K}$ Area Solid Radioactive Waste Disposal Sites .. . $\quad 31$

XIV. $100 \mathrm{~N}$ Area Solid Radioactive Waste Disposal Sites 32

XV. 200 East Area Solid Radioactive Waste Disposal Sites 33

XVI. 200 West Area Solid Radioactive Waste Disposal Sites 34

XVII. 300 Area Solid Radioactive Waste Disposal Sites 35

XVIII. 600 Area Solid Radioactive Waste Disposal Sites 36

XIX. Asphalt Pad TRU Storage 45

$X X$. VEE Trench TRU Storage 46

$X X I$. Caisson TRU Storage 48

XXII. Purex Tunnel Haste Storage 49

XXIII. Solid Waste Burial Trench 51

XXIV. NonTRU Solid Waste Burial Caissons 52

XXV. Package Approval Flowchart 55 
RHiO-CD-78

\section{ABSTRACT}

A review and assessment is made of the Hanford low level solid radioactive waste management sites and factlittes. Site factors considered favorable for waste storage and disposal are (1) limited precipitation, (2) a high deficiency of moisture in the underlying sediments (3) great depth to water table, all of which minimize radionuclide migration by water transport, and (4) high sorbtive capacity of the sediments.

Facilities are in place for 20 year retrievable storage of transuranic (TRU) wastes and for disposal of nontransuranic radioactive wastes. Auxiliary facilities and services (utilities, roads, fire protection, shops, etc.) are considered adequate. Support staffs such as engineering, radiation monitoring, personnel services, etc., are avallable and are shared with other operational programs.

The site and associated facilities are considered well suited for solid radioactive waste storage operations. However, recommendations are made for study programs to improve containment, waste package storage $11 \mathrm{fe}$, land use economy, retrievability and security of TRU wastes. 
ASSESSMENT OF HANFORD BURIAL GROUNDS

AND INTERIM TRU STORAGE

\section{INTRODUCTION}

A review of the Hanford low level solid radioactive waste management facilities was undertaken in response to a request by the Energy Research and Development Administration (ERDA). This report describes the results of this review and is to be used along with'like reports from other major ERDA solid waste disposal sites in developing a comprehensive long-range plan for the storage and disposal of solid radioactive wastes.

This report addresses specifically identified elements which have an effect on the containment, control and retrievability of the solid radioactive wastes and on the efficiency and safety of the operation of the facilities. Comments and assessments are provided to identify significant impacts on the solid radioactive waste management program.

Previous studies of the solid waste disposal facilities have been reviewed and taken into consideration in this report. These studies are:

1. Final Report, July 1976, Dames and Moore, White Plans, New York, "Development of Monitoring Programs for ERDA-Owned Radioactive Low Level Waste Burial Sites".

2. Report, 1976, National Academy of Sciences, Washington, D. C., "The Shallow Land Burial of Low Level Radioactively Contaminated Solid Waste".

3. Report, 1975, United States Department of Interior Geological Survey, "Geology and Hydrology of Radioactive Solid Waste Burial Grounds at the Hanford Reservation, Washington".

4. Report, January 12, 1976, United States General Accounting Office, "Improvements Meeded in the Land Disposal of Radioactive Wastes - A Problem of Centuries".

This assessment covers only the burial and storage operations by ERDA contractors. The commercial waste burial ground operated by Nuclear Engineering Company, Incorporated, on the Hanford Site is not addressed in this report. 
SUMMARY AND SONCLUSIONS

The following assessment is based upon information in this document and the reference documents ( 1 and 2 ):

HANFORD ENVIRONMENT

Hydrogeological Factors

The characteristics of the Hanford Reservation are generally favorable for safe shallow land burial of solid radioactive wastes. Factors which make the site favorable include limited rainfall and high solar heat input which have resulted in a high deficiency of soil moisture in the soils and sediments. Another favorable factor in the 200 Areas is the great depth to the water table (about 60 meters). As a consequence, meteoric water does not percolate to the water table over most of the Reservation, but rather enters the ground to a maximum depth of two to four meters where the water is held by strong capillary forces. Moisture is then slowly returned to the atmosphere via evapotranspiration. The net flux of soil moisture appears to be from the water table upward in the vapor phase with the geothermal gradient acting as the principal driving force (Ref 1). In this environment, the potential for dissolution and transport of radionuclides from dry wastes by meteoric water is small.

Infiltration rates have been measured for liquid waste disposal sites and have been found to be from about 0.40 to 0.50 cubic meters per square meter per day or the equivalent of about 16 to 22 millimeters of water per hour. Thus, rainfall is rapidly absorbed by the soil where it is held by capillary forces until it is released by evaporation. Under these conditions, surface runoff is negligibly small. Exceptions exist on the steep slopes of Rattlesnake Hills, Gable Butte and Gable Mountain; however, burial grounds are located well beyond the influence of such steep topographic features. Limited local runoff and ponding may occur during periods of rapid snowmelt over frozen ground; however, deep erosion of burial grounds by this mechanism is unlikely.

Radionuclide Migration

While there is no specific program for subsurface monitoring of dry waste burial grounds, an extensive program is in place for monitoring the low and intermediate level liquid radioactive wastes discharged to subsurface facilities. Experience gained from the groundwater monitoring program associated with this latter disposal practice has shown that there has been no radioactive contamination detected in the groundwater that can be attributed to buried solid radioactive wastes. The absence of subsurface migration of radioactivity from the Hanford burial grounds could be substantiated by sampling and analyzing undisturbed sediments beneath a few selected Hanford burial grounds. Ground surface contamination has occurred on several occasions due to collapse of buried wooden containers. Procedures are now in place to properly cover all sites to avoid spread of contamination to the ground surface from decay of solid waste containers. There is some 
potential for biotic transport of radioactivity from burial grounds. Deeply rooted plants, such as Russian thistle (tumbleweed), sagebrush, and rabbitbrush, accumulate and concentrate certain radionuclides, primarily strontium. The concentration factor ( $\mathrm{Ci} / \mathrm{g}$ in the shoot divided by $\mathrm{Ci} / \mathrm{g}$ in the soil) of tumbleweeds for strontium is about 19. Effort is being made to prevent growth of deeply rooted plants in burial grounds. Research has shown that Siberian wheatgrass and cheatgrass are self-sustaining vegetation that use up soil moisture before seedlings of other plants, such as tumbleweeds, can mature.

There is limited potential for animal intrusion into buried wastes. The Townsend ground squirrel digs a burrow $1 / 2$ to 1 meter deep. The badger digs a burrow 2-1/2 to 3 meters deep. Both animals are found throughout the Hanford Reservation, but are scarce in the 200 Area plateaus. The badger avoids areas of concentrated activity by man. Burrowing animals can be discouraged by placing a thick covering of cobbles over the burial grounds.

Problems of radionuclide transport by other animals (or insects) could arise if deeply rooted plants were permitted to grow or if the soil cover was so thin that grass roots could penetrate to depth where contaminated sediments are present and subsequently carry radionuclides to the surface, making them available in potential food supplies. This problem probably constitutes the greatest long term threat of transporting radioactivity into the uncontrolled environmnent.

\section{Natural Phenomena}

Potential for flooding of the burial grounds by surface streams is limited to the probable maximum flood (PMF) of the Columbia River, which would inundate the $100 \mathrm{~N}, 100 \mathrm{D}, 100 \mathrm{DR}, 100 \mathrm{H}, 100 \mathrm{~F}$, and 300 Areas. As a consequence of such flooding, the maximum postulated dose to man would be about $6 \times 10^{-3}$ rem to the whole body in the first year. The details of this dose are discussed under natural phenomena in "The Hanford Environment as Related to Radioactive Waste Burial Grounds and Transuranium Waste Storage Facilities" (Ref 1). The 200 Areas, where the bulk of the radioactive and transuranium wastes are located, would be unaffected by the PMF.

Catastrophic Ice Age floods recurrently inundated the Pasco Basin when ice dams which blocked the Clark Fork River in Idaho were breached by glacial melt floodwaters. As many as 35 such floods purportedly occurred (based on the number of strand lines on University Mountain in Missoula, Montana). The last such flood occurred about 15,000 years ago, and stripped the surface from Spokane, Washington, through the Pasco Basin and down the Columbia River Gorge. No estimates have been found regarding the probability of such events recurring.

Conceivably, buried wastes might be exposed by ground rupture due to severe earthquakes. However, much of the regional stress resulting from the continuing low rate of deformation appears to be dissipated within the many layers of basalt as random earthquakes of low intensity. No evidence of ground rupture has been identified in any of the glaciofluvial or lacustrine deposits on/or adjacent to the Hanford Reservation. 
The Pasco Basin, in which the Hanford Reservation is located, has been recurrently filled with highly-fluid molten lavas that emanated from fissures in and around the Basin. The last known lava flow originated from a fissure near Ice Harbor Dam about eight million years ago. Ice Harbor Dam is about 50 kilometers, southeasterly, from the Hanford Meteorological Station. More recently $(6,000$ to 12,000 years ago $)$ the region has been covered by extensive ash fall from volcanoes in the Cascade Range.

Based on a ten year record, an average of 12 fires per year have occurred ranging from less than one acre to less than 32,000 acres. The median fire burns about six acres and occurs at the end of June. The largest fires have originated from cloud-to-ground lightning strikes. Burial grounds are either denuded or have a sparse covering of cheatgrass and, therefore, little fuel is available: Perimeter roadways around burial grounds would limit the spread of fires. Standard procedures for covering waste limit the amount of combustible waste that might be ignited.

The potential exists for deflation of burial grounds due to occasional high velocity winds. Deflation can be circumvented by stabilizing the surface with self-sustaining shallow rooted vegetation and/or a covering of gravel and cobbles. A composite cobble-topsoil arrangement with shallow rooted annual plants would provide protection against deflation and would prevent intrusion by burrowing animals and deeply rooted plants.

FACILITIES AND OPERATING PRACTICES

TRU Waste Storage

The facilities and operating practices now in use have been selected to provide 20 year retrievable storage in compliance with ERDA MC 0511. Some uncertainties exist in the areas of probably life of the containers, probable means and difficulty of retrieval, and stability of the wastes in storage.

Storage of the packaged TRU waste on an asphalt pad, enclosed in sheet plastic and covered with earth is expected to provide the necessary 20 year retrievable life so long as waste stability and package integrity are maintained. One of the present concerns about waste stability is the possibility of package rupture due to explosion of radiolytically generated hydrogen. Studies and testing programs now in progress indicate that packaging techniques and the inclusion of certain fillers (i.e. vermiculite) can blunt the effects of an explosion adequately to protect the integrity of the packaging. These studies will continue.

The containers are expected to provide 20 year retrievable containment, but this capability has not been verified. Corrosion of the 55-gallon drums may be a route to failure. It is known that the painted surfaces are scratched through to the metal on some occasions during the handling operations, but it is not known whether these penetrations of the protective coating will cause corrosive attack on the inside surface of the drums. Another area of concern is the possible deterioration of the packages and the accumulation of earth and trash in the interstices between the packages during the time they are uncovered. Studies are recommended to resolve these issues. 
The caisson storage provides adequate protection to personnel from high radiation level TRU wastes. Nieasured activity at the ground surface is low. However, because the waste packages are allowed to drop into the caissons, the packages sometimes rupture, resulting in contamination of the caisson interior. Retrieval of the stored TRU waste in caisson storage is based upon excavation and receovery of the entire caisson. This method of retrieval will be very expensive due to the facts that: (1) it is very large (2.7 meters diameter by 3.25 meters high) and deeply burlad ( 4.3 meters earth cover), (2) it is not designed or approved as a transportation container, and (3) a recelving and processing facility has not been identified. A new concept for disposing of these wastes is recomended.

There is presently no protection from the wind during caisson-filling operations. Operational delays often result from waiting for suitable weather conditions. Shelter for the caisson-filling operation is currently under consideration.

Retrieval of TRU-contaminated wastes from the alpha trenches will also present problems. It will be necessary to exhume the various size boxes and drums, some with relatively high surface radiation rates, from earth burial without risking damage to their integrity. They will then have to be moved to an as yet unidentified facility for further processing or storage.

Large, highly contaminated items are stored on rail cars in the Purex Railroad Tunnel. For retrieval the cars can be pulled into the Purex building canyon area where hoisting equipment is available for remote handing. Processing for final disposal may be difficult, however, because much of this equipment is quite large and contains piping and other enclosures which may contain contamination. The stainless steel construction of much of this equipment will be more difficult to decontaminate and cut up than mild steel.

Waste Burial

Disposal of nonTRU waste by burial in trenches is a routine and inexpensive method of waste disposal. The Hanford soil, which consists largely of gravel and sand, sloughs off to an angle of repose of about $45^{\circ}$ during excavation. This requires the movement of much earth for the preparation and backfilling of waste trenches. Also, the wide top and relatively narrow bottom of the resulting trench coupled with the practice of covering all radioactive waste by the end of the day results in an unfavorably low ratio of waste volume to land area. Trench design changes and improved methods are recommended for improving the land use ratio.

The caisson (silo) system provides an effective method for disposal of high dose rate nonTRU wastes while keeping exposure low. As with the TRU caissons however, the waste packages are dropped without restraint into the caisson, which raises the concern of possible problems resulting from rupture of the falling container. A study to identify alternative disposal methods is recommended. 
RHO-CD-78

Weather protection to allow use of the caisson facility during high winds or other adverse weather is currently under consideration.

Totally new types of caissons will be needed, starting in FY 1979, to accept the extremely high activity rate (up to $10^{5} \mathrm{R} / \mathrm{hr}$ ) wastes from the operation of the Fast Flux Test Facility (FFTF).

Waste Processing

Packaging capabilities from the standpoints of selection, design, and fabrication are adequate. Redesign of waste packages may be a necessary adjunct to improving other operations and facilities.

Compaction has not been practiced extensively because of the high cost of providing efficient systems, which should include glove boxes, assaying facilities, sorting facilities, and exhaust systems. Land area for waste disposal has been readily available and inexpensive to use at Hanford. Plans are now being developed to provide additional volume reduction facilities.

An incinerator for recovering plutonium from combustible scrap was in operation at Hanford for ten years unti] 1973. By current standards, this early generation unit had many desian deficiencies and it was expensive to operate. It is recommended that this unit not be reactivated.

Hanford Engineering Development Laboratories (HEDL) is developing a facility which will digest combustible wastes in concentrated sulphuric acid and nitric acid, leaving behind a residue or ash. Plutonium in the ash is readily leachable for recovery. This unit appears to have much promise for waste volume reduction. It is scheduled for cold runs in FY 1977 and hot testing in FY 1978. If the testing program proves the unit is successfu1, it may be possible to convert this unit for normal operations or else build a new facility utilizing the concept.

Support Facilities, Utilities, Offices, Change Rooms

Support facilities at Hanford are considered adequate for the needs of the storage and burial operations. Power, water, telephone systems, roads, railroads, offices, etc. were designed with flexibility and size sufficient for many major facilities. These are all adequate for the expected level of waste storage and disposal.

Security, Lighting, Fences

Security is receiving increased attention in keeping with the growing concern about radioactive wastes. All currently active storage and burial sites at Hanford area are in the 200 East and 200 West Areas. These areas have lighted perimeter fences with manned gates. Security clearance is required for admittance. The areas, including burial grounds, are routinely patrolled. A security fence has been installed around burial ground 218-W-4B which is actively receiving TRU waste; additional security measures, such as intrusion alarms and lighting, are currently under consideration. 


\section{Equipment}

The equipment now available is adequate for the methods currently being used for burial and storage of solid wastes. Revised methods of handling the drums and packages on the asphalt pad may, however, require development or acquisition of specialized equipment. The proposed development of improved trench burial operations may also incorporate types of equipment not now available at Hanford.

Maintenance, Nuclear Safety and Criticality Control, Radiation Monitoring, Personnel

These items are handled in conjunction with other operations at Hanford; they are under continued evaluation and revision, where necessary, and are capable of maintaining the level of control necessary for the adequate support of burial ground operations.

\section{Records}

Records are now being kept on all current storage and burial operations including location, type of wastes, quantities, waste form, packages, etc. Local computer programs are in operation for maintaining records of the inventories and for calculating decayed inventories. This information is also being relayed to the Sol id Waste Information Management System (SWIMS), which makes it available, as needed, to authorized people. Coverage and accessibilitity of information is sufficient for forseen requirements.

\section{General}

The facilities and operating practices now in place are providing, effectively, the minimum requirements in terms of containmnet of radioactive wastes and control of personnel exposure. Recommendations are listed for improving the reliability of TRU storage, for increased land use economy, - for increasing the utilization of volume reduction and for protecting waste operations from adverse weather. Programs are being developed to deal with these problem areas. 


\section{THE HANFORD ENVIRONMENT}

\section{GENERAL DESCRIPTION AND INFORMATION}

The Hanford Reservation, Figure I, is located in the Pasco Basin, an arid region of southeastern Washington State in the rain shadow of the Cascade Mountain Range. This section of the state has a sparse covering of natural vegetation primarily suited for grazing, although large areas near the site have gradually been put under irrigation during the past few years. Most irrigated farms near the Hanford Reservation obtain water from the Yakima and Columbia Rivers. (Reference 1 and 2)

Burial Sites and History

Energy Research and Development Administration facilities located on the Hanford Reservation include nuclear reactors for plutonium production (100 Areas); fuels reprocessing, plutonium processing, and high and low level radioactive waste management (200 Areas); fuel fabrication ( 300 Areas); a large laboratory complex (300 Area); the Fast Flux Test Facility ( 400 Area); central service facility ( 1100 Area); onsite construction services (3000 Area) and administrative services (700 Area). A large segment of the site is undeveloped and serves as a buffer zone (600 Area). Two large nuclear power reactors are currently being constructed by the Washington Public Power Supply System, north of the 300 Area.

\section{Topography}

The Hanford Reservation to the south and west of the Columbia River is a broad plain, most of which ranges in elevation from about 120 meters to about 170 meters above mean sea level. The 200 Areas, near the west central portion of the Reservation, are located on ancestral Columhia River bar that ranges in elevation from about 180 meters to about 230 meters above mean sea level (this bar is locally referred to as the 200 Area Plateau). Gable Butte and Gable Mountain are two anticlinal ridges just north of the center of the Reservation. Gable Butte rises about 60 meters above the adjacent land area and Gable Mountain about 180 meters. Rattlesnake H111s. which form the southwestern boundary, have a maximum elevation of 1091 meters.

The Columbia River is about 120 meters above mean sea level at Vernita, where it enters the northwest corner of the Hanford Reservation, and is abnut 104 meters above mean sea level near the 300 Area at the southeastern boundary.

The burial ground sites are located on flat to gently sloping ground. Surface erosion is essentially nonexistant because of low rainfall, high infiltration rates and flat terrain.

Land Use

Land within an $80 \mathrm{kilometer} \mathrm{radius} \mathrm{of} \mathrm{the} \mathrm{Hanford} \mathrm{Reservation} \mathrm{is} \mathrm{used} \mathrm{for}$ grazing, for growing wheat, and for growing irrigated farm crops. An 


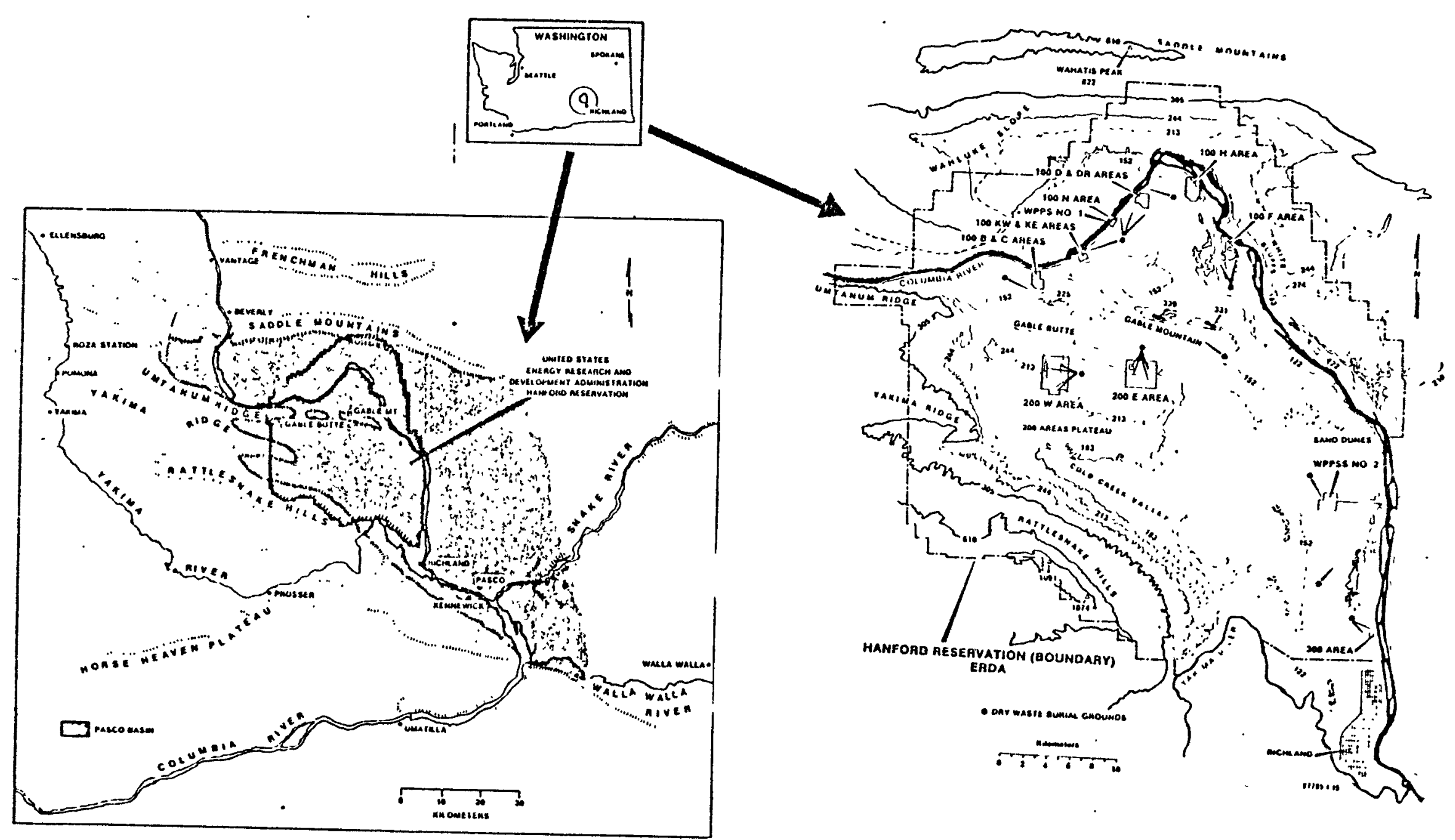

FIGURE-I

GEOGRAPHY OF THE HANFORD RESERVATION 
estimated $2.5 \times 10^{8}$ cubic meters of water are taken annually from the Columbia River, Yakima River, and from wells for this puroose.

\section{Landmarks}

Natural landmarks in the area include the Saddle Mountains immediately to the north. This range of hills trends east-west; Wahatis Peak (905 meters) is the highest point along the ridge. The Columbia River, which flows through the northern portion of the-Hanford Reservation and then along the eastern boundary, provides another natural landmark as do the White Bluffs. rising 60 to 90 meters along the eastern shoreline of the river. The southwestern edge of the Reservation is marked by the Rattlesnake Hills. Gable Mountain and Gable Butte are marked geological features which lie near the center of the Reservation. A parallel series of northwest-southeast trending ridges, notably Yakima and Umtanum Ridges, extend from the Reservation boundary 100 kilometers westward to the foothills of the Cascade Range.

\section{Climatology}

The Hanford climate is mild and dry, with occasional periods of high winds. Summers are generally hot and dry: winters are relatively mild with some precipitation. The temperature normally ranges from about $10^{\circ} \mathrm{C}$ in the winter to $46^{\circ} \mathrm{C}$ in the summer. The average annual precipitation is 160 millimeters. Forty-two percent of the annual precipitation occurs during November, December and January; whereas only ten percent occurs in july, August, and September. A slight secondary maximum precipitation occurs in late spring.

Mean monthly wind speeds range from about 8 kilometers per hour in the winter to 15 kilometers per hour in the summer. The prevailing wind directions are from the north-northwest through northwest. The strongest winds tend to be from the southwest. The highest observed peak wind gust of 65 kilometers per hour or greater has been observed on the average of at least once in every month of the year, although the winter months tend to have a higher frequency of high wind periods. High level winds over the site have been studied. Ground released balloon observations show that higher level winds tend to exhibit stronger westerly components than surface winds.

Tornadoes are infrequent in this region and tend to be small with little damage when they do occur. A single small tornado has been observed onsite, but no damage was reported. Fourteen tornadoes have been confirmed within 160 kilometers of the Hanford Reservation between 1916 and the present.

The number of thunder storm days at Hanford result in an estimated annual lightning-strike frequency of 0.022 for a building about 9 meters high. This would be about one strike per 46 years.

Anthropology and Demography

Before the arrival of Europeans the Columbia River area was one of the most densely inhabited regions in North America. The native Indian tribes lived largely on fish from the Columbia River and its tributaries and on natural 
plant products. Evidences of this 11 feway have been virtually erased, therefore the Hanford Reservation sites assumes qreat archeological significance and is being evaluated under a research grant with Washington State University. The majority of sites lie close to the Columbia River.

The earliest use by white immigrants of the Hanford Reservation was for stock grazing in a seasonal pattern. In the first decade of the twentieth century, several small, privately irrigated farms were put into cultivation within the Pasco Basin. The Hanford Irrigation Project, taking water from the Columbia River upstream from the $100 \mathrm{~K}$ Areas, supplied a small but flourishing irrigated orchard and farm economy along the river as far downstream as the sand dune area north of the Washington Public Power Supply System Number 2 Reactor, Figure I, until the government purchased the land to construct the Hanford Engineering Works.

It is estimated that 250,000 people (12 per square kilometer) currently live within an 80 kilometer radius of the Hanford Meteorological Station (HMS), which is located near the center of the Hanford Reservation.

\section{Geology}

The Pasco Basin is underlain by three principal rock types: dense, hard basalt (Columbia River basalt) which forms the bedrock beneath the area; semiconsolidated lake and stream sediments (Ringold Formation) directly overlying the bedrock; and unconsolidated sands, silts and gravels (Hanford Formation) carried into the area by glacial flood waters during the close of the Ice Age.

The general stratigraphic position of these three main rocks is shown in Figure II, which is a diagrammatic cross section of a portion of the Hanford Reservation. Also, photographs of typical exposures of the sedimentary deposits commonly observed in the Pasco Basin are shown in Figure II.

The Columbia Basin basalt flows in the Pasco Basin have accumulated to a thickness of over 3,200 meters as determined from deep exploratory drilling. In 1968, the Atlantic Richfield Hanford Company (ARHCO), on behalf of the U. S. Energy Research and Devleopment Administration, cored several holes in the basalt near the center of the basin. A cross section is shown in Figure III summarizing the correlations made between core holes and the data from the nearby canyon sections. The marker flows (highlighted in a darker shade of grey) were identified on the basis of their unique chemical properties.

Between 20 and 40 million years ago, the site of the Pasco Basin was situated in or near the center of a regional topographic low area, analogous to a large saucer with a 300 kilometer diameter. Beginning about this time, a series of large cracks (fissures) opened up in the ground surface around the periphery of the basin and large volumes of molten basalt poured out over the land surface. 


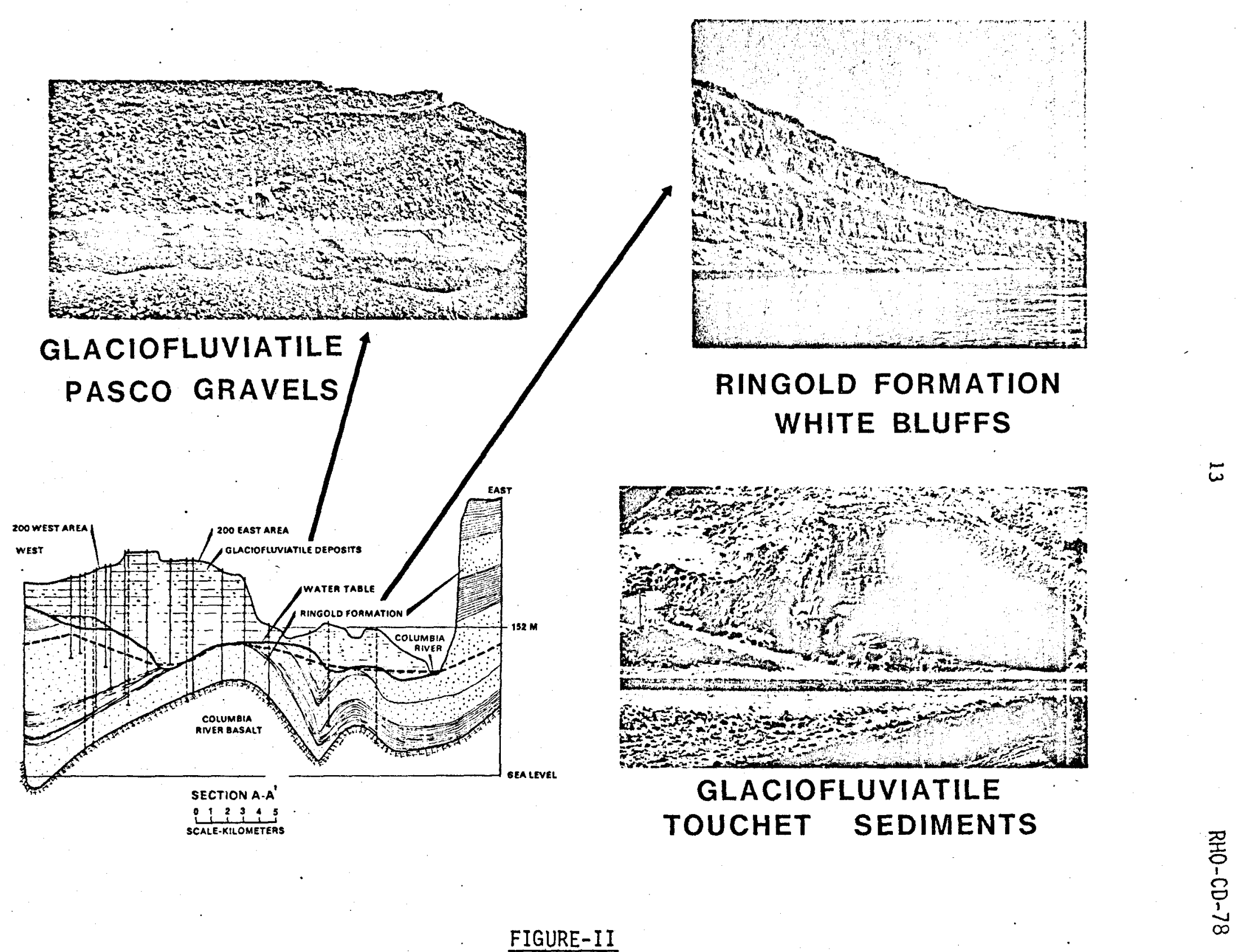

SEDIMENTARY ROCKS OVERLYING THE COLUMBIA RIVER BASALT IN THE PASCO BASIN 

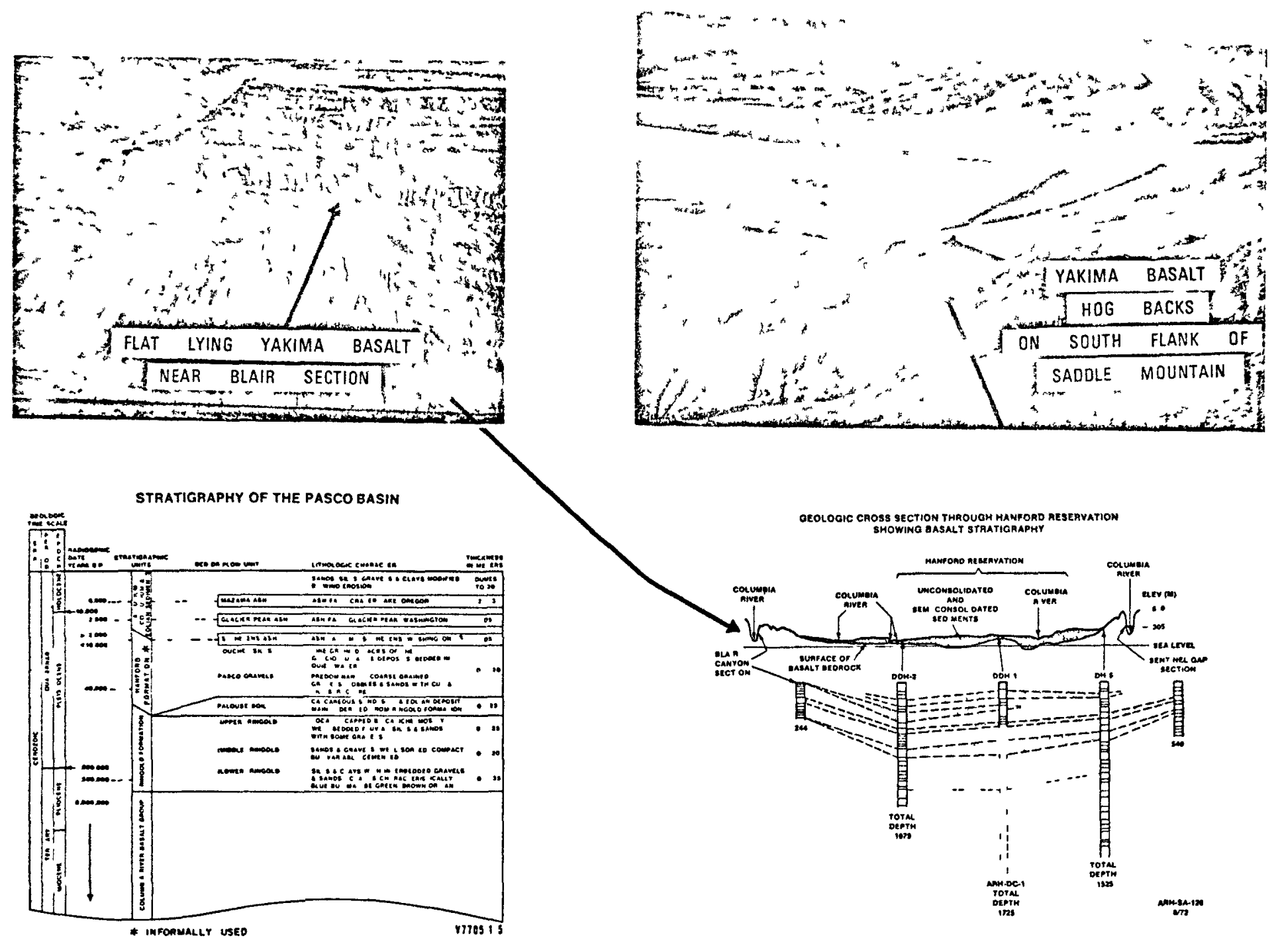

FIGURE-III

GENERAL STRUCTURE OF THE YAKIMA BASALTS IN THE PASCO BASIN 
The fluidity (viscosity) of the basalt lava was about the same as water. Under these conditions, the molten rock quickly ran downhill filling the lowland areas in the center of the basin. Subsidance, however, kept pace with the inflow of lava accounting for the great thickness now observed in the Pasco Basin. It has been determined that several cubic kilometers of lava per day flowed into the Pasco Basin during one eruption.

There were periods when little volcanic activity occurred. Lakes, connected by streams and rivers, existed in the region, and into these bodies of water sediments accumulated. With renewed eruptions, the sedimentary deposits were in turn covered by more basalt. Thus extensive deposits of volcanic ash, tuffs, sands, silts and clays are intercalated between many of the basalt flows.

About 15 million years ago, the relatively flat surface of the region began to buckle slowly, creating a series of ridges and smaller basins including the Pasco Basin. Lava flows entering the Pasco Basin during the last stages of volcanic activity tended to settle in the lowland regions and lap up against the flanks of the ridges on the older basalt flows. The age of the last flow which entered has been determined to be $8+0.2$ million years.

Following the cessation of the volcanic activity, basining continued. In this basin, a shallow lake was formed. The ancestral Columbia River Transported sediments into the basin where they began accumulating in the bottom of the lake. These sediments are known today as the Ringold Formation.

The sedimentary rocks of the Ringold Formation are conformable with the surface of the underlying bedrock. These sediments can be differentiated into three distinct units, as shown in the stratigraphic chart, Figure III. The upper silt zone of the Ringold Formation is exposed along the 80 kilometer stretch of the Columbia River upstream from the 300 Area. The term "White Bluffs" has come into common usage because of the light buff color of these silt bluffs. On the east bank of the Columbia River.

The total thickness of these lake sediments is in excess of 370 meters, rising more than 200 meters above the level of the Columbia River. Marked changes in the types and sizes of sediments from one horizon to another indicate significant changes in the flow rate of the rivers from time to time.

The unconsolidated glacial-outwash sands, silts and gravels of the Hanford Formation directly overlay the Ringold Formation. The coarser sediments are locally referred to as the Pasco gravels and the finer grained sediments are called Touchet Sediments, see stratigraphic chart in Figure III.

During the close of the Ice Age, perhaps 18,000 years ago, the continental ice sheet, which covered much of northern Washington, melted and gradually retreated northward. As a result, several catastrophic floods of glacial meltwater were released. It has been estimated that in one flood alone over $2 \times 10^{3}$ cubic kilometers of water poured into the Pasco Basin at a rate of more than 40 cubic kilometers of water per hour (Reference 1). The 
block diagrams, Figure IV, were constructed to depict the possible sequence of events that occurred in the Pasco Basin 18,000 years ago when this catastrophic flood occurred. The sediments deposited from these floods in the Pasco Basin are called the Hanford Formation, Figure III.

Following the last flood, about 8,000 years ago, the ground surface in the Pasco Basin was further modified by the prevailing strong westerly winds. Figure $V$ shows two types of dunes found on the Hanford Reservation and which are common to the Pasco Basin.

Most of the ridges and hills (anticlines) in the Pasco Basin are asymmetrical in shape. The anticlines have gently sloping south limbs and steeply dipping north limbs. A picture of the Yakima Basalt on the south flank of Saddle Mountain is shown in Figure III. These beds dip about 30 degrees to the south. The north 1 imb of Saddle Mountain dips 75 to 85 degrees to the north.

The few faults that have been mapped in the Columbia Plateau appear to be directly related to the folds within the basalt. Folding appears to have been the primary response of the basalts in the Columbia Plateau to tectonic deformation, and faulting appears to have been secondary. In general, the faults found within the basin are: (1) of limited length, generally less than 20 kilometers; (2) of minor offset, usually less than 60 meters; and (3) characterized by the absence of structural features associated with recent fault activity. The Saddle Mountains fault, on the north side of Saddle Mountains, appears to be less than 50 kilometers long but may be over 100 kilometers long. It is a normal fault, with maximum cumulative displacement estimated at 500 meters. No offsets of sediments younger than about one million years old can be documented.

The Wallula Fault is 50 kilometers southeast of Richland. This northwest trending fault is associated with several minor faults, generally less than eight kilometers in length. Displacement on the Wallula Fault is estimated to be between 40 and 90 meters. This structure also aligns with the proposed olympic Wallowa lineament that separates a major change in rock types at Snoqualmie Pass in the Cascade Mountains to the west and connects with an area of significant earthquake activity to the southeast at Milton-Freewater and is therefore, considered to be about 130 kilometers long. The Rattlesnake-Wallula structure is considered to be, at the present, the closest and largest structure capable of producing a major earthquake in the region.

Hydrology

From a hydrologic standpoint, the Hanford Reservation is composed of a series of confined aquifers (primarily basaltic interbeds of the Columbia River Group) overlain by an unconfined aquifer in the permeable beds of the upper and middle Ringold and in the overlying sediments of the Hanford Formation.

Since these materials are very heterogeneous, often greater lithologic differences appear within a given bed than between beds. The top of the aquifer at any time is the water table, Figure VI. The aquifer bottom is the basalt bedrock in some areas and silt/clay zones of the Ringold formation in other areas. 

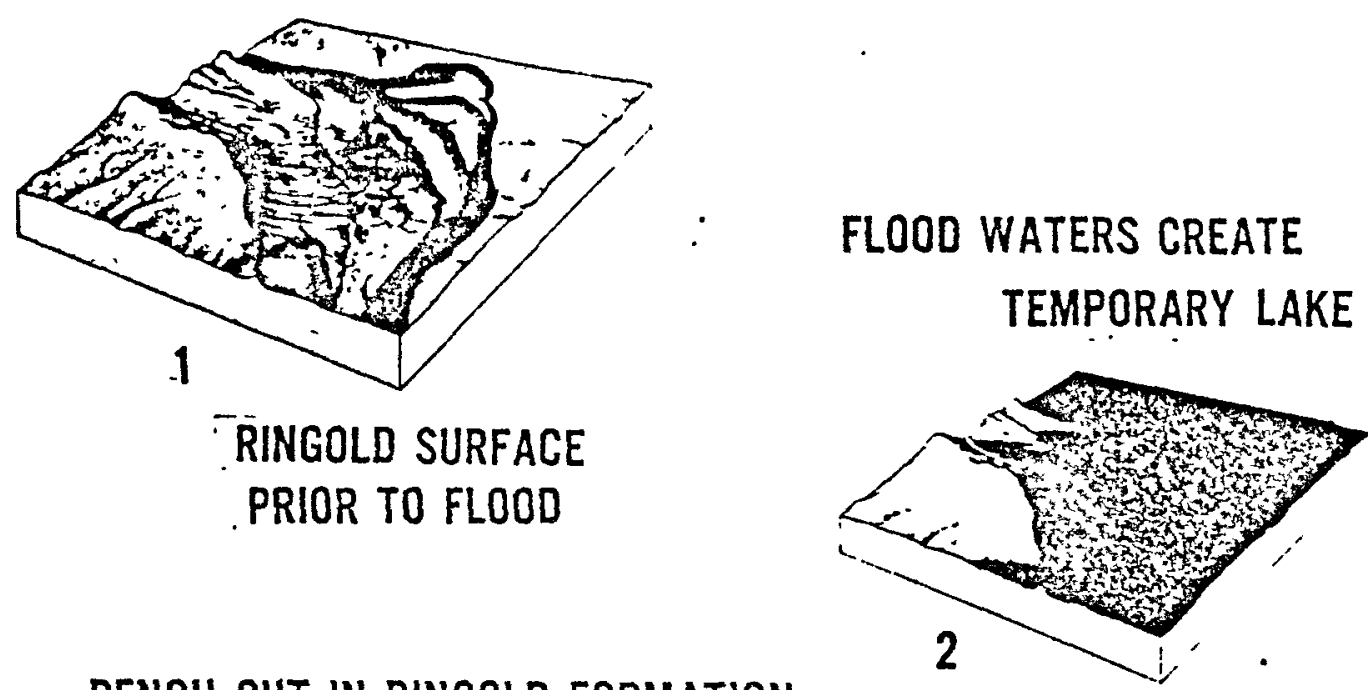

BENCH CUT IN RINGOLD FORMATION

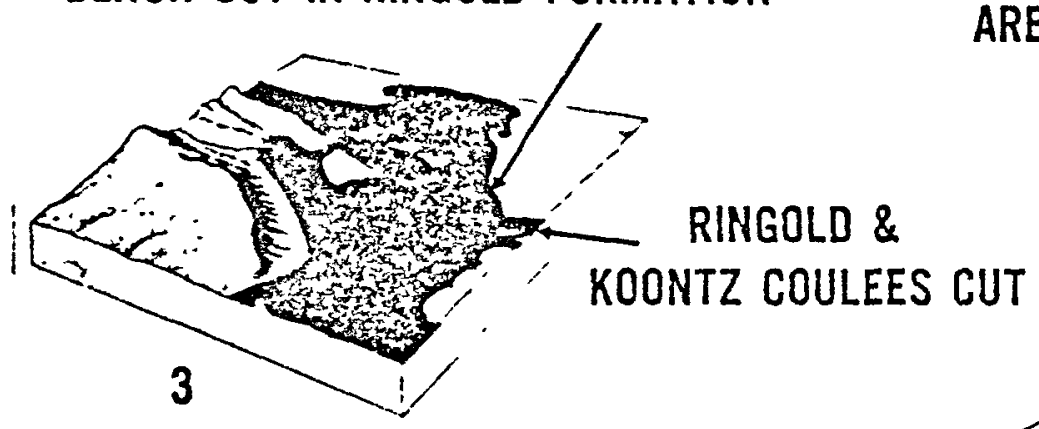

AREA INUNDATED

FLOOD WATERS RECEED

ICE RAFTED DEPOSITS

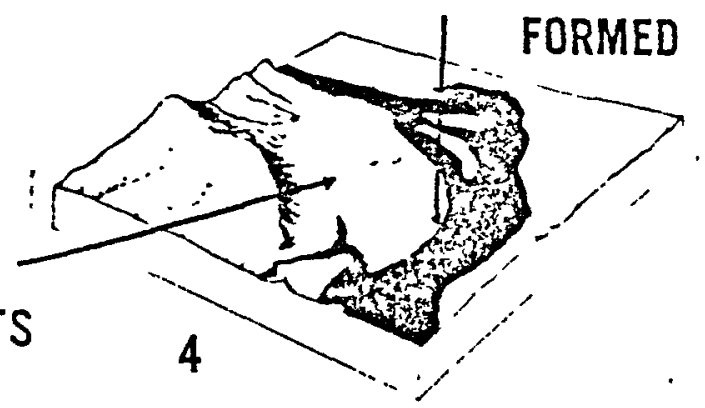

$\therefore$

FLOOD WATERS CONTINUE TO RECEED

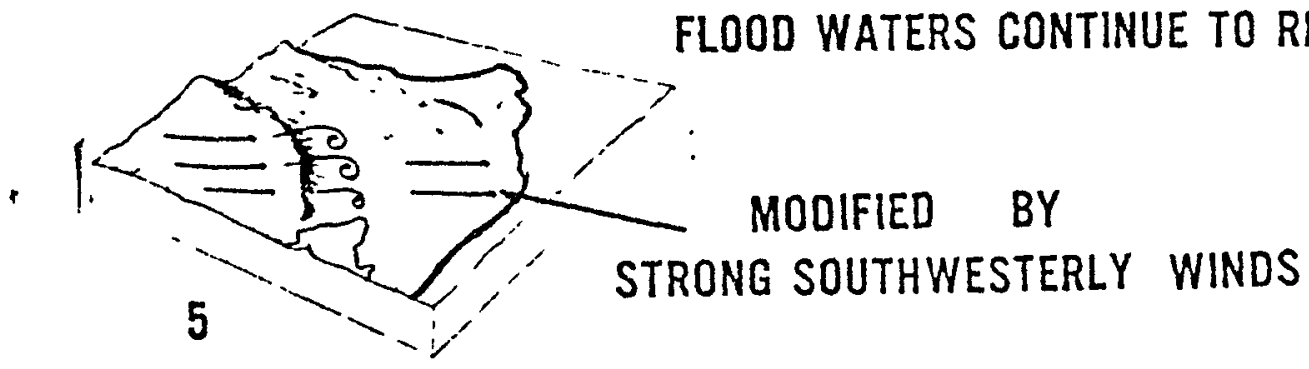

PRESENT GROUND SURFACE 

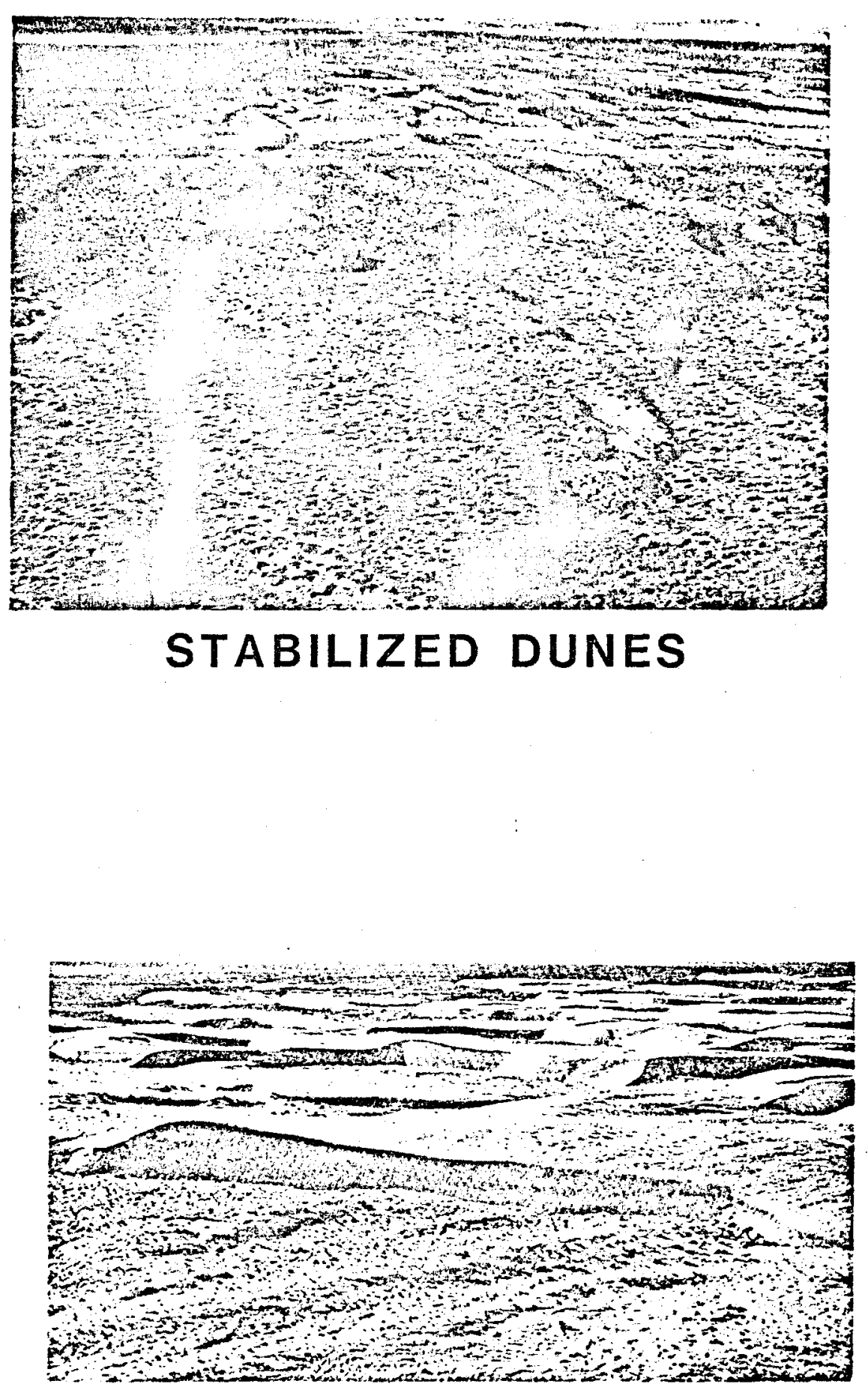

ACTIVE DUNES

\author{
FIGURE $V$
}

DEPOSITONAL FEATURES RELATED TO PAST AND PRESENT WIND EROSION 
The water table over the western portion of the Hanford Reservation lies at the top of the Ringold Formation. However, between the high terrace plateaus and the Columbia River, the water table rises above the Ringold sediments and intersects overlying permeable glaciofluviatile deposits of the Hantord Formation.

The critical factor that controls the nature of the unconfined aquifer within the Hanford Reservation is the extent of the Columbia River downcutting that took place during Ringold and post-Ringold times. Sizeable paleochannels of very high permeability were formed as a result of such downcutting. The nature and location of the paleochannels have been studied using a gravity survey.

The flow pattern that originally prevailed in the unconfined aquifer prior to discharing large volumes of water was primarily to the west and northeast with discharge into the Columbia River, (Figure VIC). Natural recharge occurs at the foot of Rattlesnake Hills and Yakima Ridge, where surface flow sinks into the floor of the valley.

The surface water bodies located within the boundaries of the Hanford Reservation, Figure VIa, consists of the Columbia River, various ditches and waste water ponds associated with the 200 Areas, and three waste water ponds located in the 300 Area. Two ephemeral streams, Cold Creek and Dry Creek, appear for a short time only after a heavy rainfall or snowmelt. The Yakima River borders part of the Reservation's southern boundary.

A calculation of the effects of a 100 year flood of the Columbia River on the waste management operations has been performed and reported (Reference I). This calculation shows that under these circumstances, burial grounds at $100 \mathrm{D}, 100 \mathrm{DR}, 100 \mathrm{~F}, 100 \mathrm{H}$, and 300 Areas would be flooded. The $100 \mathrm{KE}$, $100 \mathrm{KW}, 100 \mathrm{~B}, 100 \mathrm{C}$, and 200 Areas would be above flood areas.

The probably maximum 24 hour precipitation that canbe expected in the Hanford region at least once in a million years is 280 millimeters. The maximum recorded 24 hour precipitation has been 48.5 millimeters. Nonetheless even the 280 millimeter 24 hour downpour would not cause appreciably significant flooding. Runoff is essentially negligible.

The unsaturated (vadose) zone has been defined by the U. S. Geological Survey's Committee on Redefinition of Groundwater Terms (Reference I) as: "...the zone between the land surface and the water table. Characteristically, this zone contains liquid water under less than atmospheric pressure, and water vapor and air or other gases usually at atmospheric pressure. In parts of this zone, interstices may be temporarily or permanently filled with water. Perched water bodies may exist within the unsaturated zone."

The movement of water in the unsaturated zone is influenced by the physical properties of the sediments in two ways: (1) the size and structural arrangement of the sediment particles determine the space configuration through which the water moves; and (2) the interaction between the sediments and the water gives rise to water moving forces. In sediments where pores 
are completely filled with water, the fluid is a single phase. Where water completely fills the pores, the water potential depends on the gravitational field and on the absorptive and cohesive forces associated with the intersticial boundaries in the sediments. Where air partially fills the soil pores with water occupying the remaining void space, a two-phase flow can take place. As the percentage of liquid water decreases, it occupies smaller and smaller capillaries that exist between soil particles.

The rate and direction of moisture movement in the arid Hanford soils are being measured in two lysimeters, 3 meters in diameter by 18 meters in depth (Reference I). The lysimeters are filled with uniformly mixed soil to eliminate variables caused by stratification. One lysimeter is sealed at the bottom to intercept percolating water; the other, as a control, is open to the underlying sediments. Data collected since 1971 have demonstrated that all of the incident precipitation is returned to the atmosphere by evaporation (Figure VII).

\section{ECOLOGY}

Vegetation

The Hanford Reservation is referred to as a shrub-steppe grassland. The most conspicuous or abundant plant species are:

100 Areas - Cheatgrass/tumble mustard, willow and other riparian vegetation

200 Areas - Sagebrush/cheatgrass or Sandbert bluegrass

300 Areas - Sagebrush - bitterbrush/cheatgrass

The most broadly distributed vegetation type is the sagebrush/cheatgrassbluegrass association. Hopsage, rabbitbrush, balsam root and tumble mustard may be intermingled with sagebrush. Small willow communities occur along the banks of the Columbia River and ponds in the 200 Areas. The willows and associated deciduous trees, shrubs and herbaceous plants provide valuable food and nest sites for game and song birds and summer forage and cover for mule deer.

The historical pattern of plant succession in the stepppe region of Washington was altered during the past century by the introduction of annual weeds from Eurasia. One of the most aggressive of these plants is cheatgrass which is well adapted to the fall-winter precipitation regime of the area and is more competitive than the native perennial grasses (Reference I). Agricultural fields abandoned for 30 years continue to be dominated by cheatgrass; apparently the competition for soil, water and available essential mineral nutrients is sufficient to exclude other kinds of plants for long periods.

Tumbleweed, another exotic plant, is not as competitive as cheatgrass in most habitats, but is the most successful colonizer of habitats where cheatgrass is suppressed by mechanical means or herbicides or in soils with heterogeneous texture. In the absence of physical disturbance, cheatgrass and tumbleweed are not effective in invading pristine steppe communities. Nevertheless, cheatgrass and tumbleweed will tend to become more important 


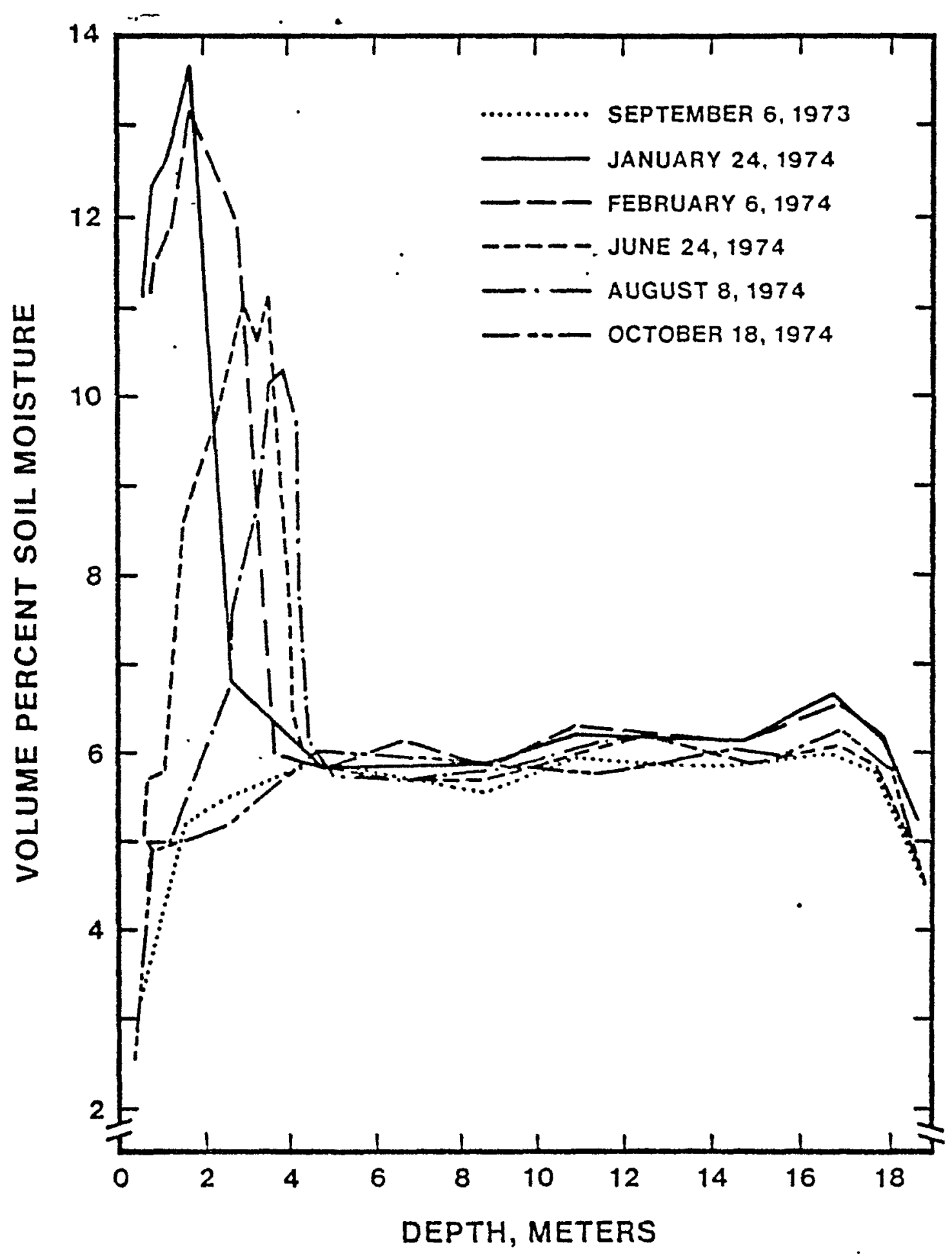

FIGURE VII

HANFORD SOIL MOISTURE CONTENT 
on the Hanford Reservation as more soil is disturbed by construction and waste burial activities.

Mamma Is

The mule deer is the only big game mammal normally found on the Hanford Reservation, living mostly along the Columbia River with smaller concentrations near Gable Mountain and the 200 Areas.

The cottontail rabbit is the most abundant small game mamal with populations scattered throughout the Reservation. Beaver, muskrat, mink, raccoon, and procupine are found mostiy on shoreline areas of the Columbia River and waste ponds in the 200 Areas. The coyote is commonly found on the Reservation, as is the black-tailed hare. Bobcat and badger are present in small numbers. Small manmals are abundant, particularly the Great Basin pocket mouse. Deer mice, ground squirrels, and pocket gophers are abundant.

Birds

The chukar partridge is the most important upland game bird on the Hanford Reservation. Chinese ring-necked pheasants and sage grouse are present, but in small numbers, and California quail are present as scattered local populations along the Columbia River. Mourning doves are migratory birds that nest throughout the Reservation area during the spring months. The most abundant birds in steppe vegetation are the western meadowlark and the horned lark.

The Canada goose is the most important of the nesting waterfowl on the Hanford Reservation, the nesting habitat is confined to islands in the Columbia River. The Columbia River also provides a resting sanctuary for migratory flocks of ducks and Canada geese. At peak migratory periods, 70,000 birds (mostly mallards) occupy the Hanford reach of the Columbia River (Reference I).

Raptorial birds use the Hanford Reservation as a refuge from human intrusions, especially during the nesting season. Red-tailed hawks, Swainson's hawks, marsh hawks, burrowing owls, great horned owls, and prairie falcon all nest in the area. The sparrow hawk is the most abundant of the raptorial birds. The golden eagle and the bald eagle are both winter visitors. Relatively large areas of uninhabited land, such as the Reservation, provide a valuable nesting and foraging ground for raptorial birds.

Snakes and Lizards

The most abundant reptile is the side-blotched lizard, while the horned lizard and the sagebrush lizard are seen rarely. The most abundant snake is the gopher snake, but the yellow-bellied racer and the Pacific rattlesnake are common. The coachwhip snake and the desert night snake are seldom observed.

Insects

Insects are abundant throughout the major plant communities on the Reservation and in ditches as well. Mealybugs, which occur in 
assoclation with bluebunch wheatgrass, are espectally abundant. Grasshoppers are conspicuous herbivores throughout the area. Population outbreaks of the migratory grasshopper have occurred in the past. Darkling beetles are another dominant insect group widely distributed on the site. Hymenopteran species (ants, wasps, bees) are common; especially the harvester ants which readily invade disturbed areas such as burial grounds. Dragonflies are abundant near ponds and ditches during summer months.

Hanford Biota

The dynamic interplay of the many organisms residing in an ecosystem can be grasped by considering the energy transfers between the various biota existing within the ecosystem. The major biota existing on the Hanford Reservation (exclusive of microbiota) is shown in Figure VIII. Each group, including herbivores and carnivores, is dependent ultimately on the plant community. 


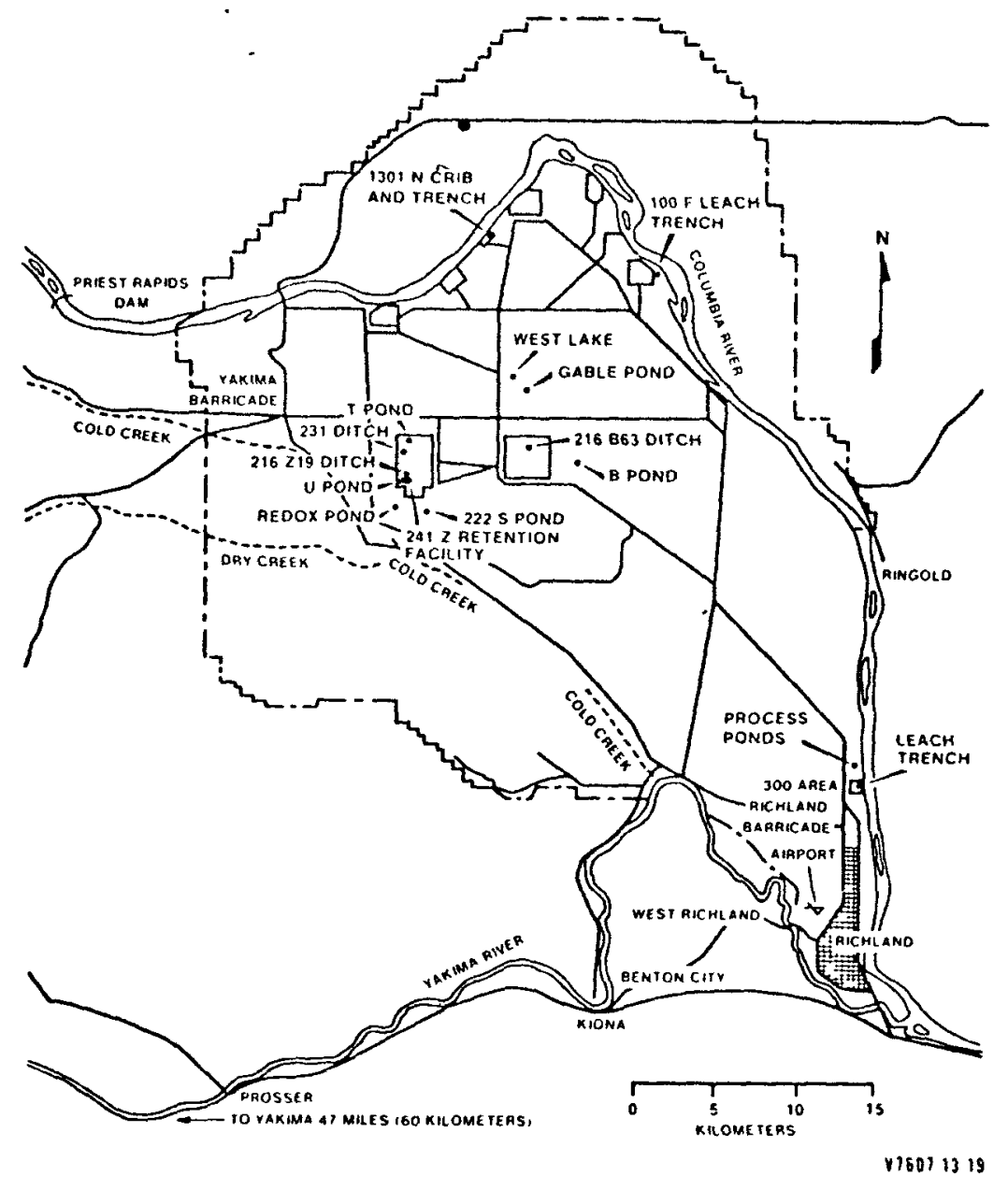

SURFACE WATER BODIES

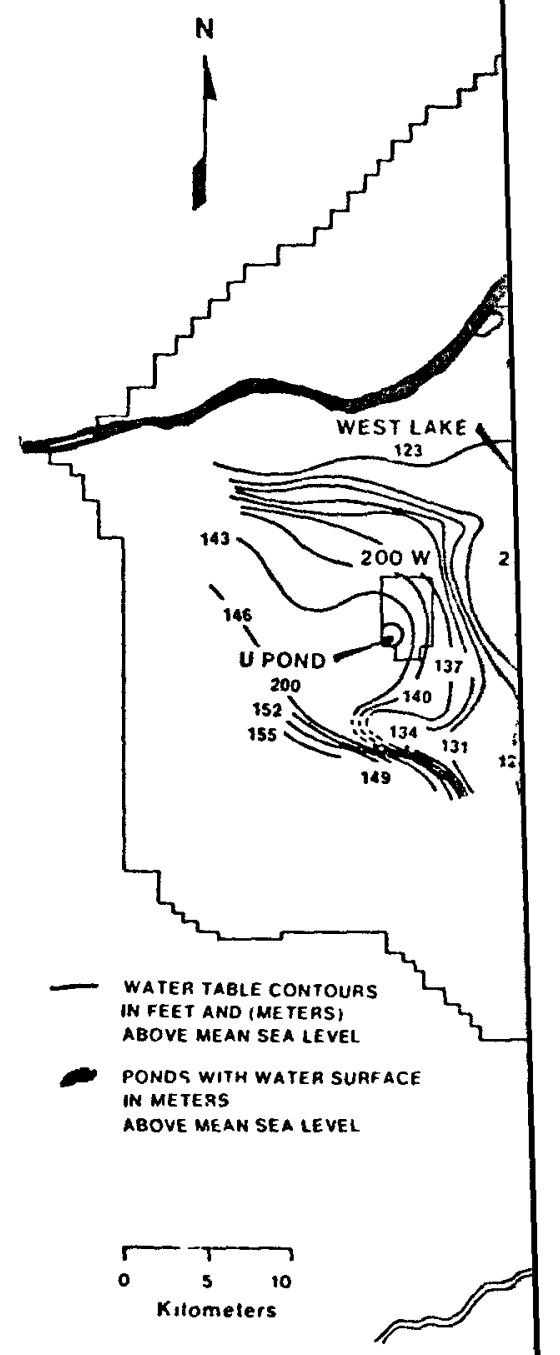

WATER TAB

(JANU) 

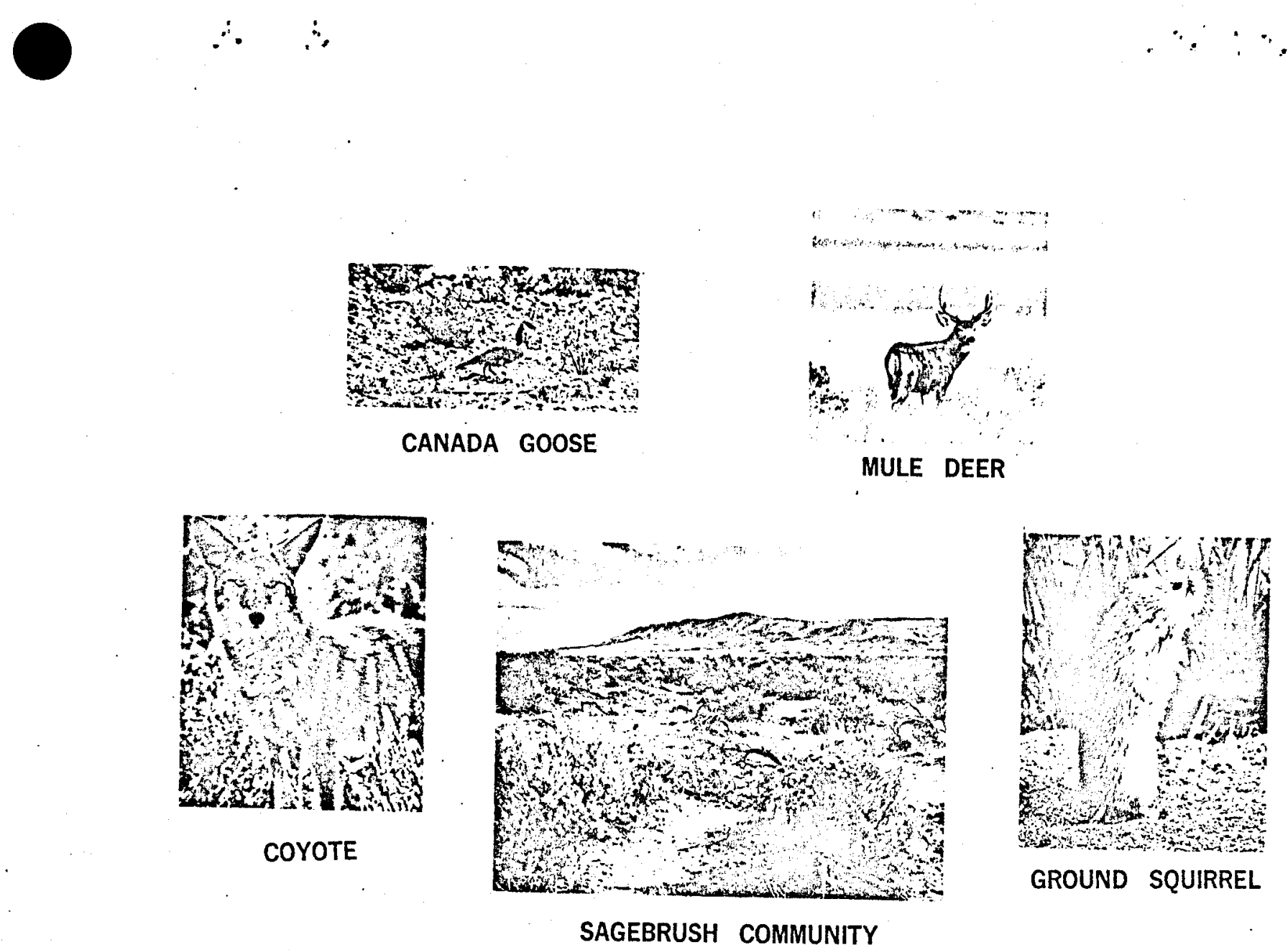
HANFORD SOLID WASTE BURIAL GROUNDS

\section{BURIAL SITES AND HISTORY}

Solid wastes contaminated with radioactivity have been disposed of by shallow earth burial at the Hanford site since the beginning of operations in 1944. Burial grounds were provided and used in all of the operating areas. A total of 26 sites in the 100 Areas (about $2.6 \times 10^{5}$ square meters), 28 sites in the 200 Areas (about $6.8 \times 10^{5}$ square meters) and 11 sites in the 300 and 600 Areas (about $2.6 \times 10^{5}$ square meters) have been used for the storage and burial of solid radioactive waste.

Burial grounds in the 100 and 300 Areas are relatively close to the Columbia River and are mainly underlain with permeable materials. Depth to water varies from about 5 to 25 meters. Wastes buried in the $100 \mathrm{~F}$ burial grounds are very near the water table, while those at other 100 Area sites are approximately 10 meters above the water table. Burial grounds located on the 200 Areas plateau are underlain by considerable thicknesses of low permeability materials. Wastes buried here are 55 meters or more above the water table. Vadose water movement beneath these burial grounds has virtually undetectible flow and the soil has a large capacity for ion exchange, which will remove and retain radionuclides.

Historically, virtually all of the radioactive wastes were buried in the area which they were generated. Beginning in 1968, however, increasing amounts of waste were transported to the 200 Areas for disposal. Since 1973 essentially all of the solid waste generated at Hanford has been stored or buried in the 200 Areas. Since May 1, 1970, all of the radioactive solid wastes contaminated or potentially contaminated with more than $10 \mathrm{nci} / \mathrm{g}$ transuranic (TRU) radionuclides have been packaged and stored in the 200 Areas for retrieval during an interim period of up to 20 years duration, in response to ERDA MC 0511 .

Solid waste storage and burial sites are shown in the following figures.

\section{INVENTORIES AND CURRENT RECEIPTS}

Records were not kept on the amount and types of radionuclides buried as solid waste in the early days of the project. During the 1950's and the $1960^{\prime} \mathrm{s}$, some documents were issued on waste disposal activities, but these records were not complete. Beginning in the late 1960's, routine reports of radioactive waste disposal in the 100 and 200 Areas have been more complete, including the land area used, the volume of waste, the curies of the specific radionuclides, and the coordinates of the location. Studies (Reference 3 and 4 ) have been made which estimate the volume and radioactivity of previously unrecorded wastes buried in the 100 and 200 Areas based upon the ratio of the nuclides present in the fuel elements and on other known and deduced waste generation and disposal information. A computer program has been used to calculate the decayed inventories remaining in the burial grounds. Inventory records are not complete on the solid wastes in the 300 and 600 Areas burial grounds. 


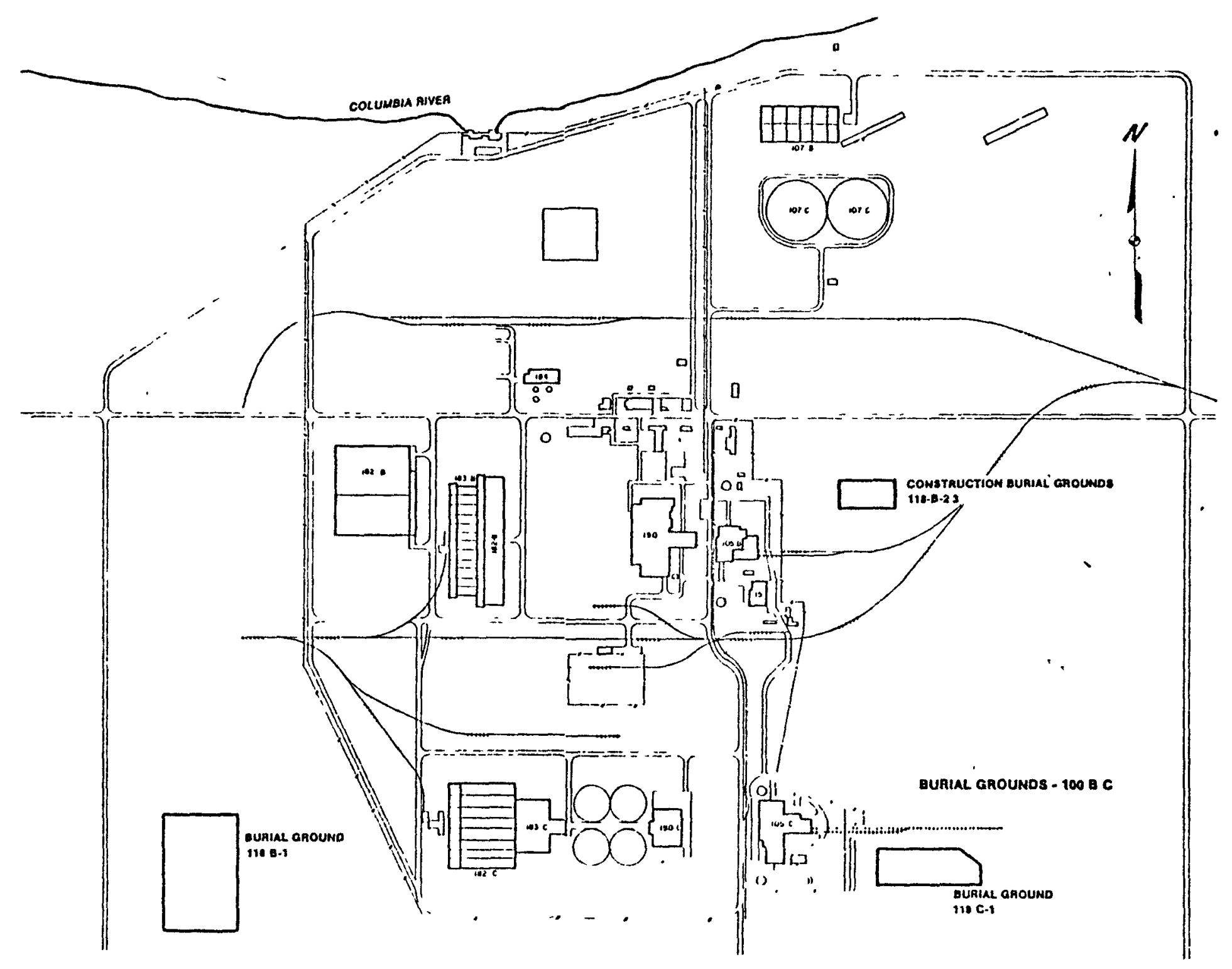




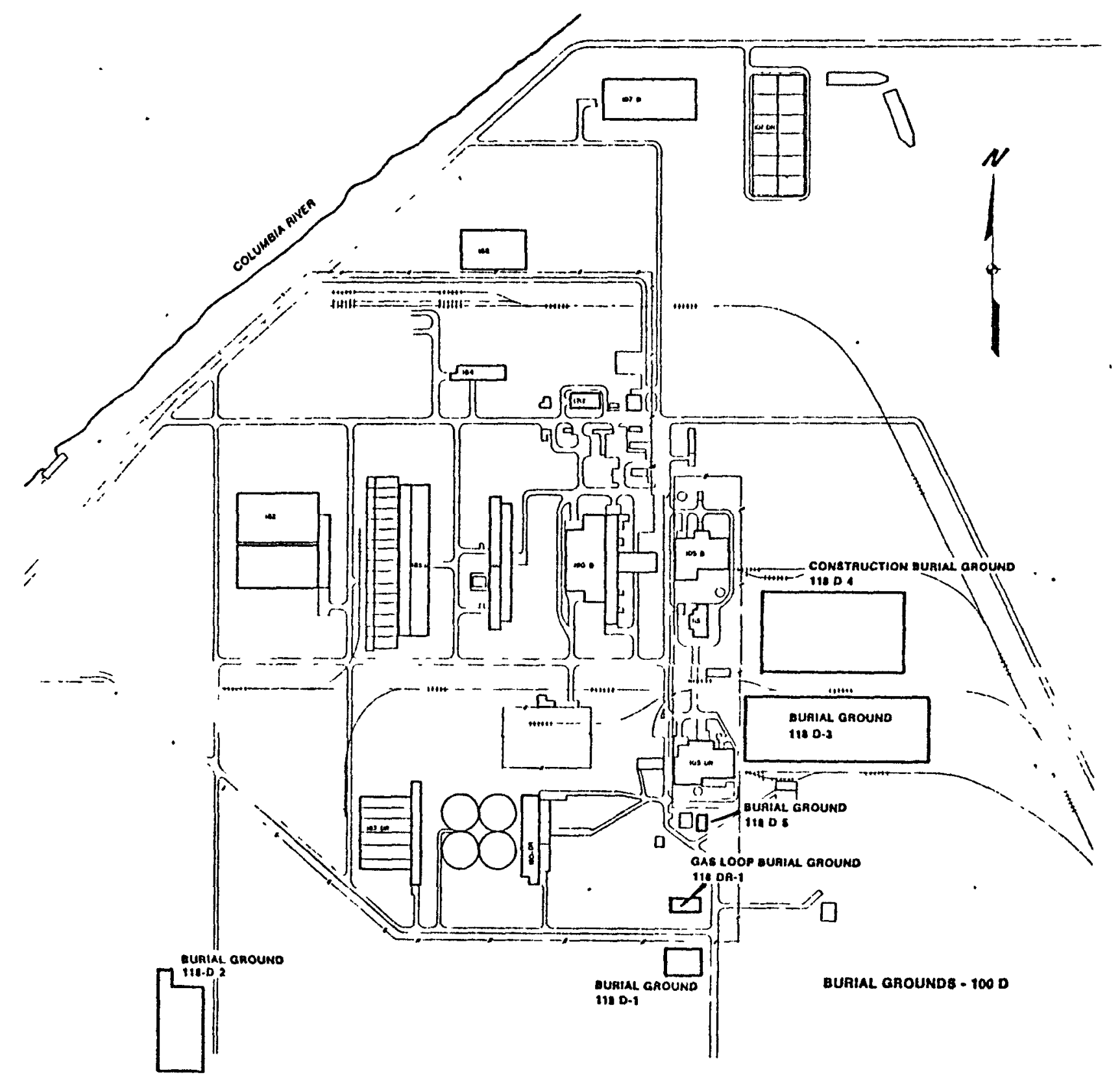




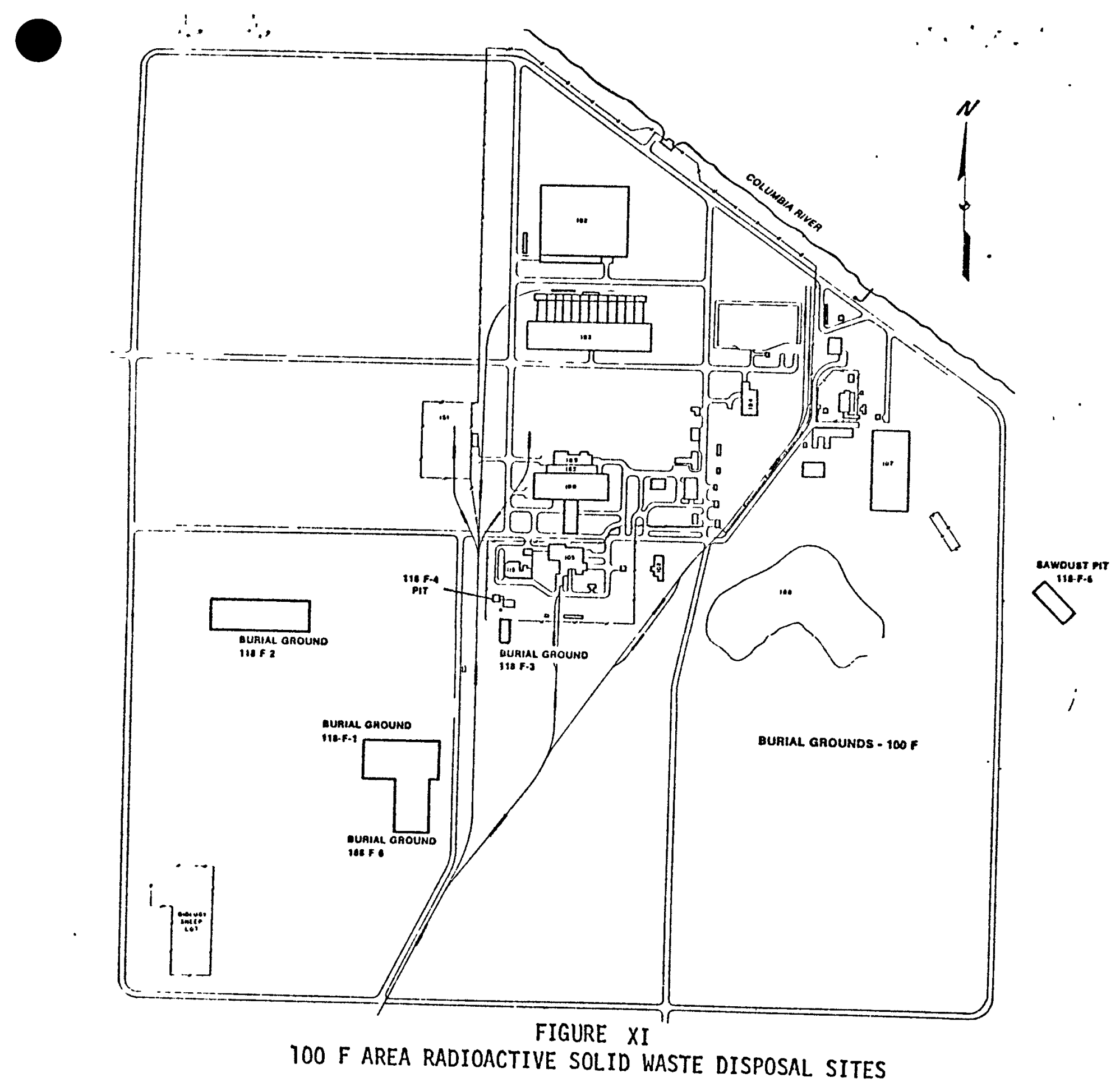



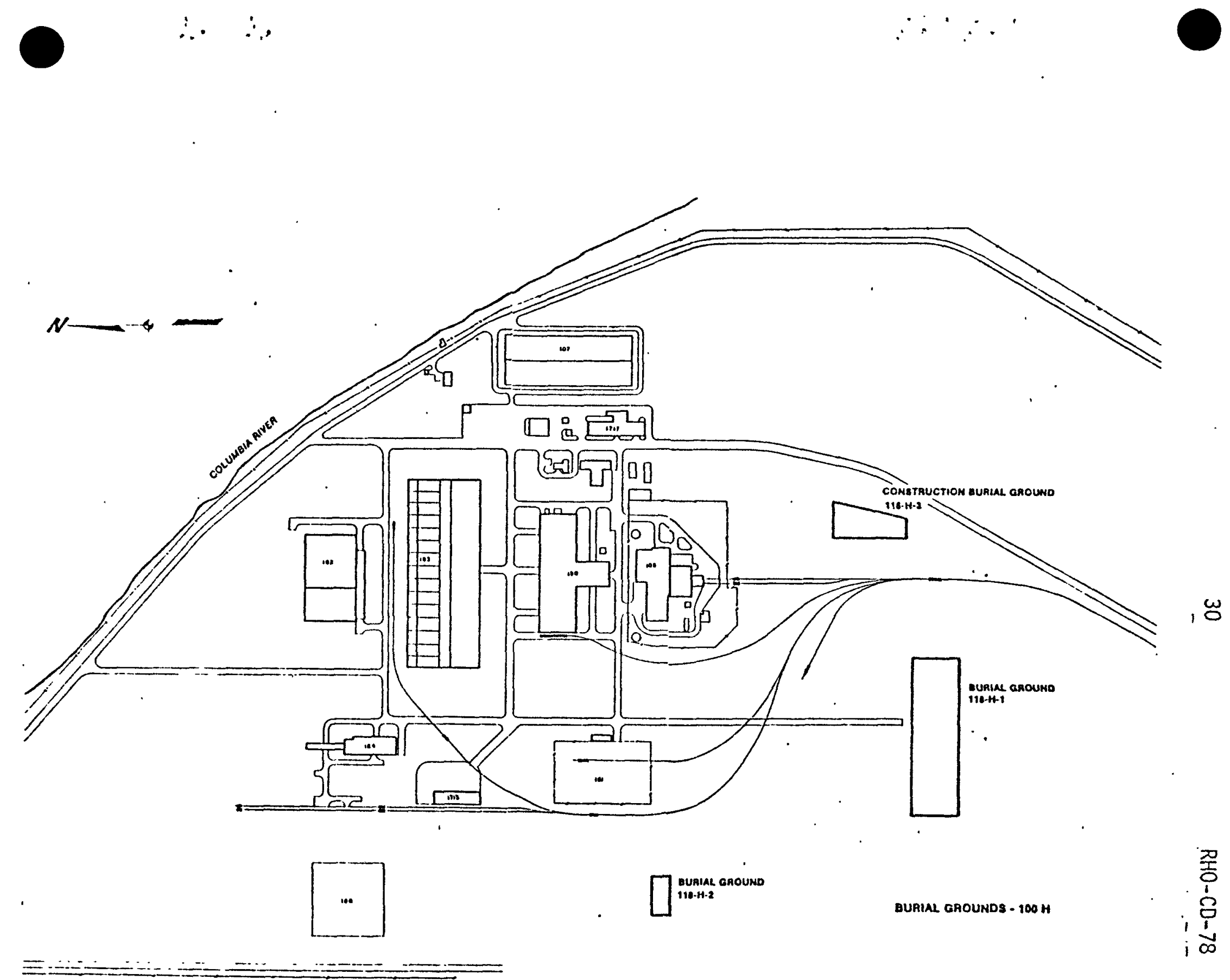

FIGURE XII

IDO H AREA RADIOACTIVE SOLID WASTE DISPOSAL SITES 


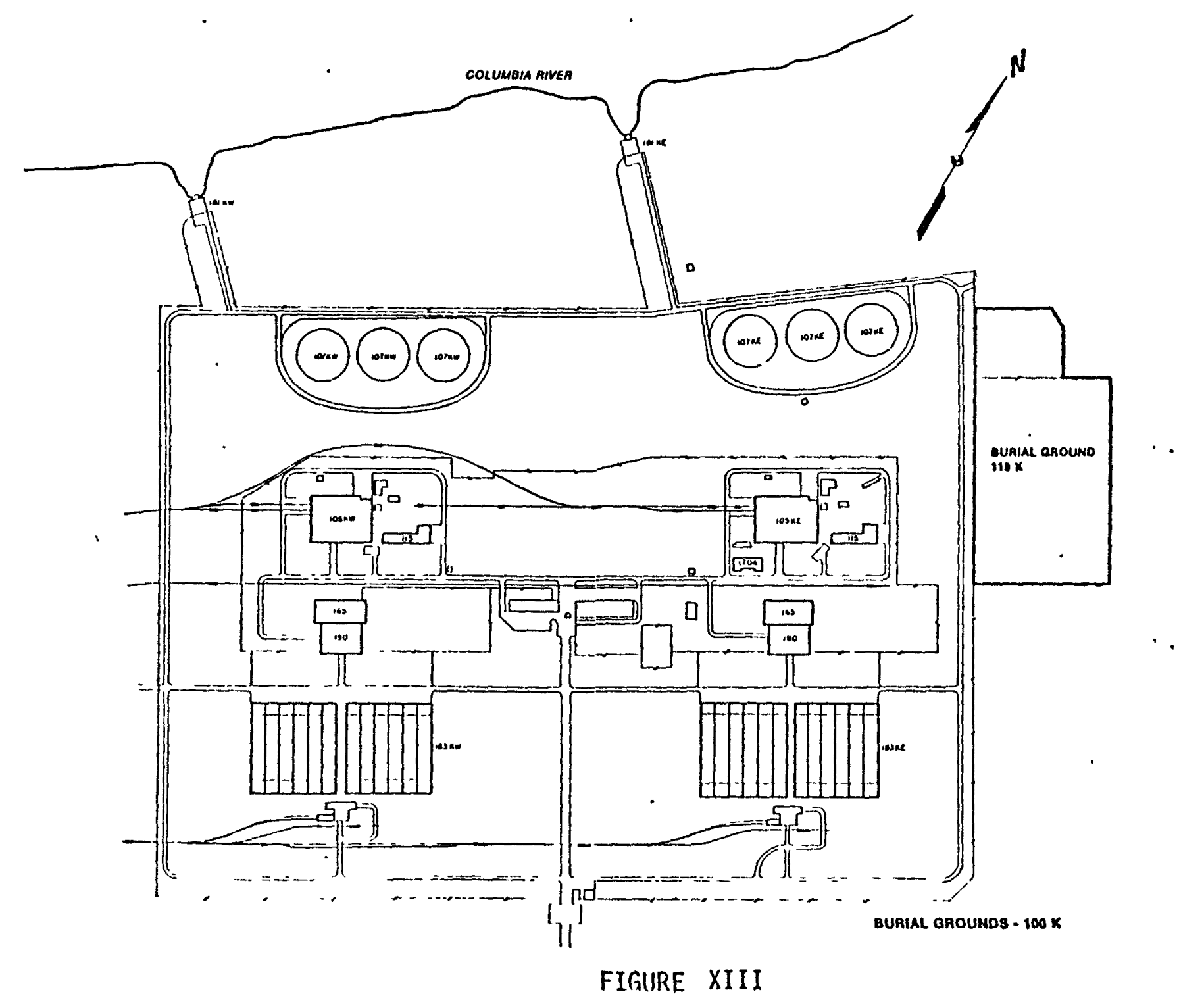



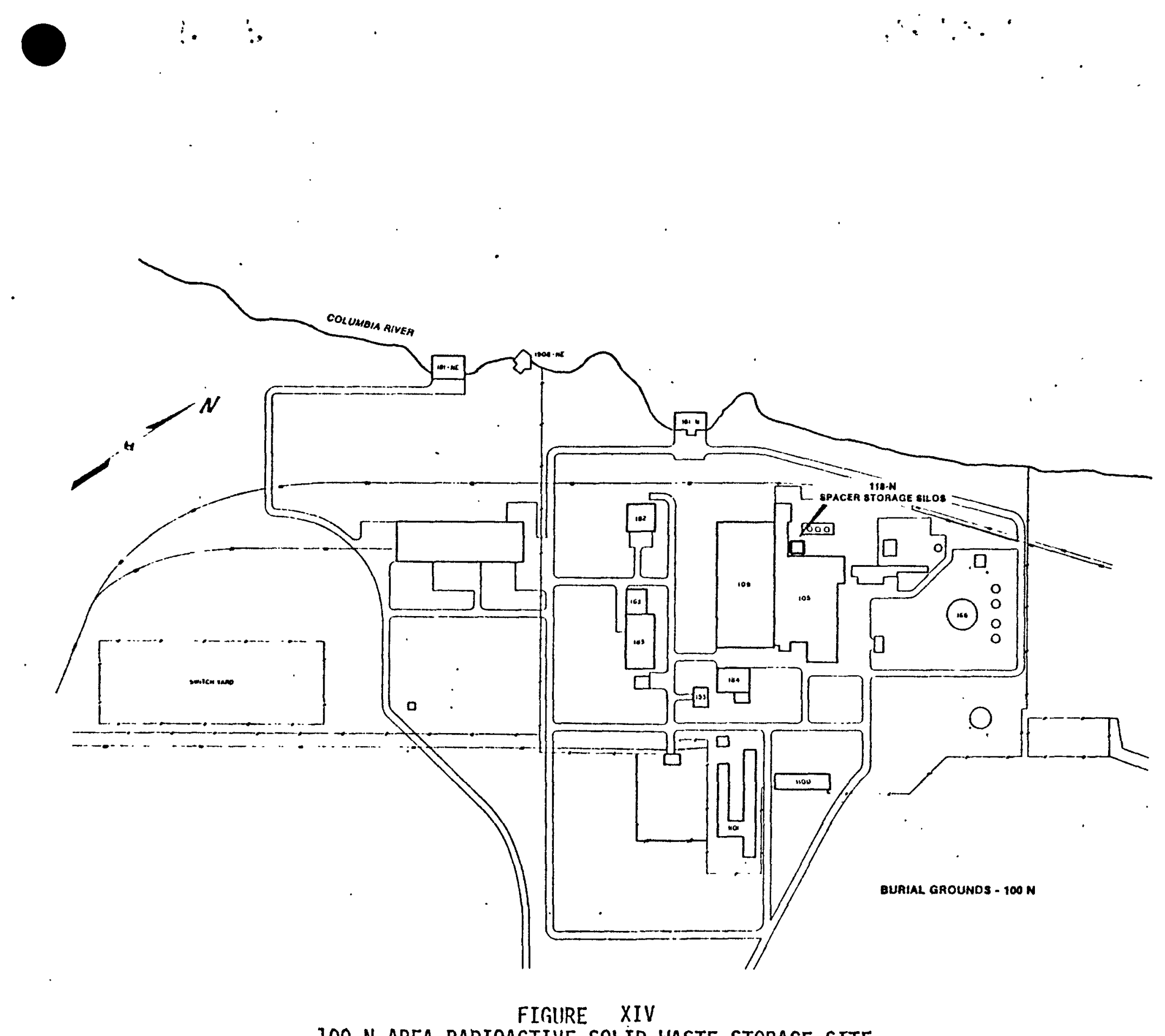


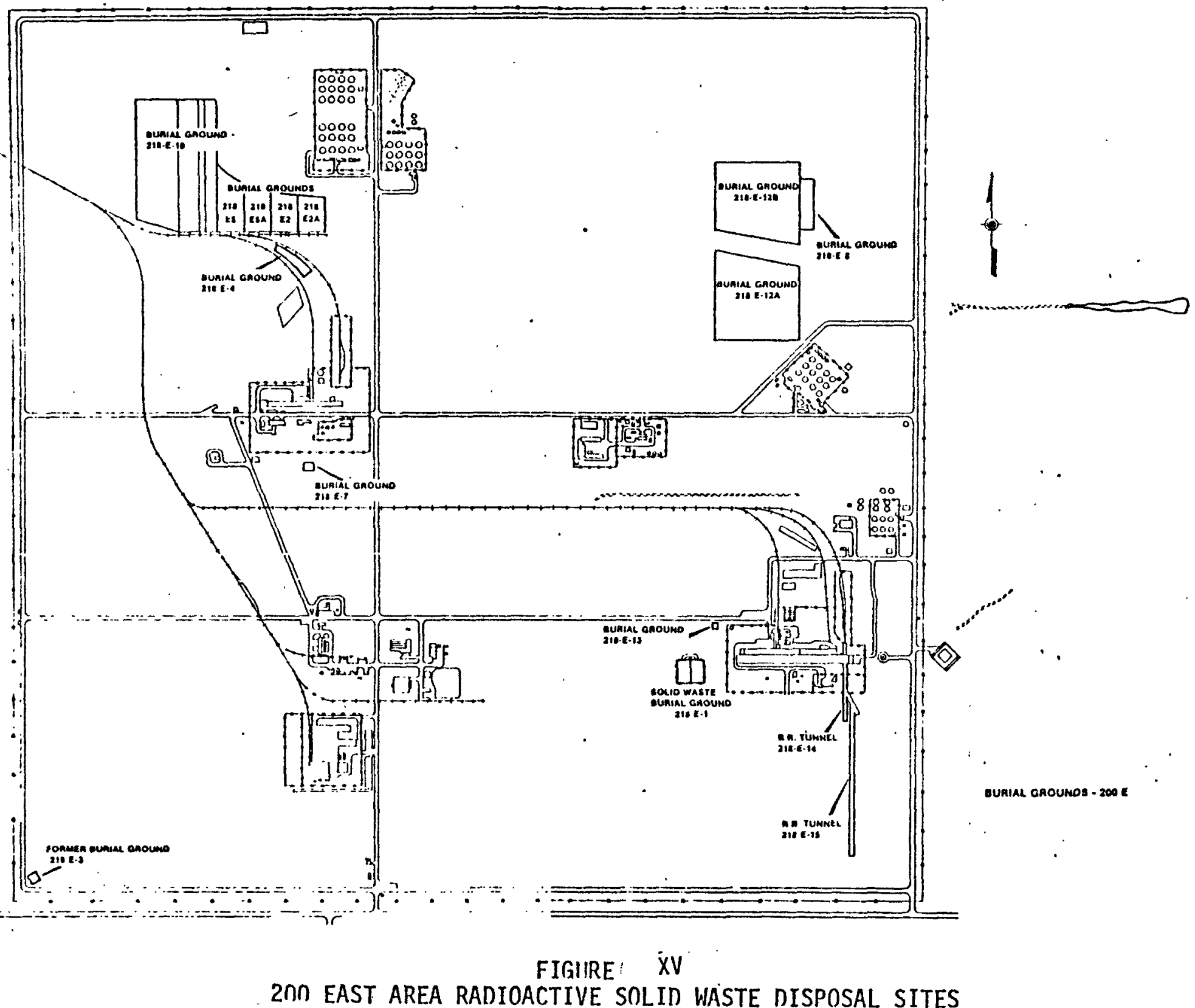

$\omega^{\prime}$

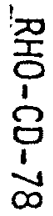

20 EAST AREA RADIOACTIVE SOLID WASTE DISPOSAL SITES 


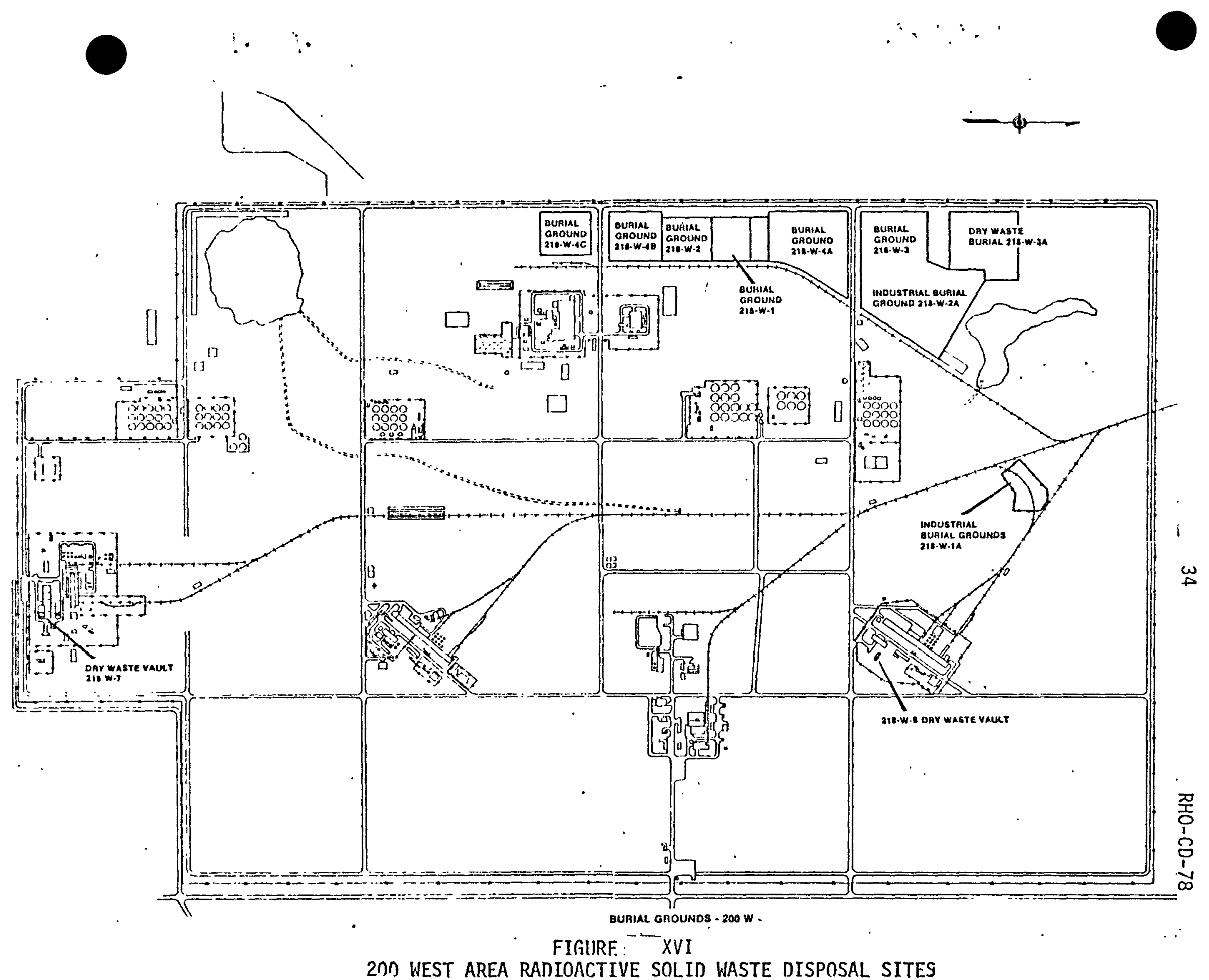





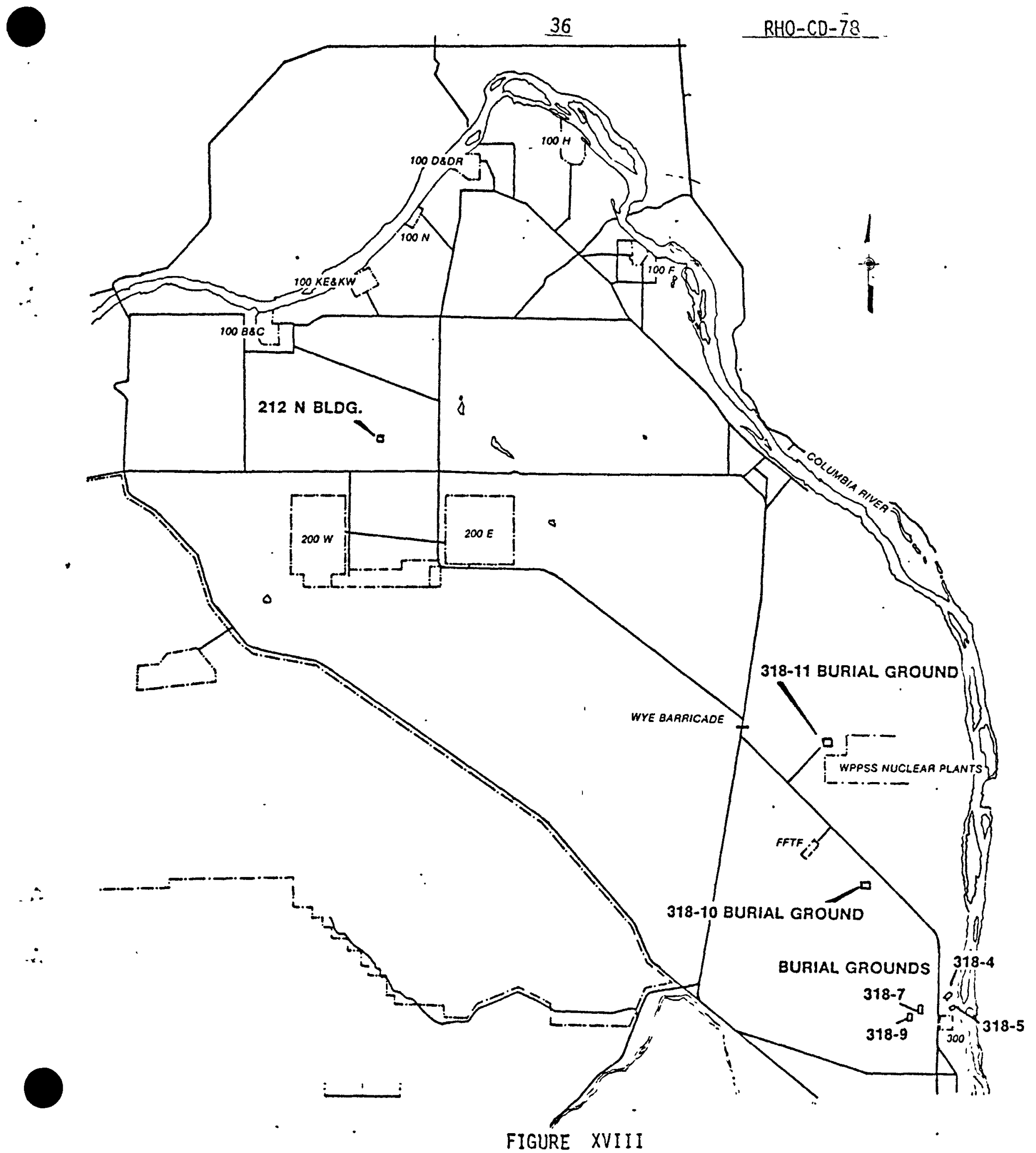


Waste quantities and land areas are listed by location in Tables I through $V$. The reported inventories are based upon actual records when available and the estimates of earlier burials. Wastes in the 100 Area are listed by reactor area and not by specific burial grounds, where the distribution of the wastes is not exactly know.

Table VI shows a breakdown of the types and quantities of waste put into storage and burial in fiscal year (FY) 1976. Forecasts show that these quantities are expected to increase fractionally in the immediate future, with no major changes in the distribution of the types of waste.

Beginning in FY 1979, additional quantities of high activity wastes are expected from the startup and operation of the Fast Flux Test Facility (FFTF) and associated activities. 


\section{TABLE I}

SOLID RADIOACTIVE WASTE STORAGE AND BURIAL SITES 100 AREAS

\begin{tabular}{|c|c|c|c|}
\hline Number & Type & Area (sq. m) & $\begin{array}{l}\text { Depth to } \\
\text { Water Table } \\
\text { In Meters } \\
\end{array}$ \\
\hline $118-B-1$ & Trenches & $3.0 \times 10^{4}$ & 26 \\
\hline $118-B-2$ & Trenches & $1.70 \times 10^{2}$ & 18 \\
\hline $118-B-3$ & Trenches & $9.0 \times 10^{3}$ & 18 \\
\hline $118-B-4$ & Pits & $1.4 \times 10^{2}$ & 18 \\
\hline $118-B-5$ & Trenches & $2.3 \times 10^{2}$ & 18 \\
\hline $118-B-6$ & Pits & $1.5 \times 10^{2}$ & 26 \\
\hline $118-c-1$ & $\begin{array}{l}\text { Trenches } \\
\text { Pits }\end{array}$ & NA & \\
\hline $118-0-1$ & Trenches & $1.6 \times 10^{4}$ & 22 \\
\hline $178-0-2$ & Trenches & $1.4 \times 10^{4}$ & 19 \\
\hline $178-0-3$ & Trenches & $2.6 \times 10^{4}$ & 22 \\
\hline $178-D-4$ & Trenches & $2.6 \times 10^{4}$ & 22 \\
\hline $118-0-5$ & Trenches & 40 & 22 \\
\hline $118-D R-1$ & Trenches & $8.7 \times 10^{2}$ & 22 \\
\hline $118-F-1$ & Trenches & $3 \times 10^{4}$ & 4 \\
\hline $118-F-2$ & Trenches & $1.1 \times 10^{4}$ & 4 \\
\hline $118-F-3$ & Trenches & $8.1 \times 10^{2}$ & 10 \\
\hline $118-F-4$ & Pits & 10 & 10 \\
\hline $118-F-5$ & Pits & NA & 10 \\
\hline $118-F-6$ & Trenches & NA & 4 \\
\hline $118-H-1$ & Trenches. & $2.3 \times 10^{4}$ & 13 \\
\hline $178-H-2$ & Trenches & $7 \times 10^{2}$ & 13 \\
\hline $118-H-3$ & Trenches & $6 \times 10^{3}$ & 13 \\
\hline $118-H-4$ & Trenches & $4.2 \times 10^{2}$ & 14 \\
\hline $118-H-5$ & Trenches & 60 & 14 \\
\hline $118-K$ & Trenches & $6.6 \times 10^{4}$ & 13 \\
\hline $118-N$ & Silos & 40 & 17 \\
\hline
\end{tabular}




\section{TABLE II}

\section{SOLID WASTE BURIAL SITE INVENTORIES \\ 100 AREAS}

\begin{tabular}{|c|c|c|}
\hline Location & $\begin{array}{l}\text { Total Area } \\
\text { (Sq. m.) }\end{array}$ & $\begin{array}{l}\text { Inventory }(C i) \\
\text { As of } 1972 \\
\end{array}$ \\
\hline $100 \mathrm{~B}$ & $>1.7 \times 10^{4}$ & $3,500(\mathrm{Co}-60)$ \\
\hline 1000 & $8.2 \times 10^{4}$ & $4,000(\mathrm{Co}-60)$ \\
\hline $100 \mathrm{~F}$ & $4.1 \times 10^{4}$ & \\
\hline Solid Waste (Production Reactors) & & $1,900(\mathrm{Co}-60)$ \\
\hline Solid Waste (Research) & & $15(5 r-90)$ \\
\hline \multirow[t]{2}{*}{ Sawdust Respository (Research) } & & $15(s r-90)$ \\
\hline & & $0.3(P u-239)$ \\
\hline $100 \mathrm{H}$ & $>2.3 \times 10^{4}$ & $3,500(\mathrm{Co}-60)$ \\
\hline $100 \mathrm{~K}$ & $6.7 \times 10^{4}$ & $13,000(\mathrm{Co}-60)$ \\
\hline
\end{tabular}


TABLE III

SOLID RADIOACTIVE WASTE STORAGE AND BURIAL SITES 200 EAST

\begin{tabular}{|c|c|c|c|c|c|c|}
\hline Number & Type & $\begin{array}{l}\text { Area } \\
\text { (Sg. m.) }\end{array}$ & $\begin{array}{l}\text { Waste Vol. } \\
\text { (Cu. m.) }\end{array}$ & $\mathrm{Pu}, \mathrm{Kg}$ & $B, Y C i$ & Status \\
\hline $218-E-1$ & Trenches & $1.0 \times 10^{4}$ & $3.1 \times 10^{3}$ & 0.9 & 4.2 & Inactive \\
\hline $218-E-2$ & Trenches & $2.0 \times 10^{4}$ & $9 \times 10^{3}$ & 0.8 & 1,100 & Inactive \\
\hline $278-E-4$ & Trenches & $1.4 \times 10^{4}$ & $1.6 \times 10^{3}$ & 0.01 & 0.49 & Active \\
\hline $218-E-5$ & Trenches & $9.5 \times 10^{3}$ & $3.1 \times 10^{3}$ & 0.62 & 370 & Inactive \\
\hline $218-E-5 A$ & Trenches & $2.1 \times 10^{4}$ & $6.2 \times 10^{3}$ & 1.38 & 865 & Inactive \\
\hline 218-E-7 & Vaults & $1.8 \times 10^{2}$ & $1.7 \times 10^{2}$ & 0.001 & 26 & Inactive \\
\hline $218-E-8$ & Trenches & $7.0 \times 10^{3}$ & $2.2 \times 10^{3}$ & 0.02 & 0.53 & Inactive \\
\hline $278-E-10$ & Trenches & $7.4 \times 10^{4}$ & $1.5 \times 10^{4}$ & 4.9 & 10,800 & Active \\
\hline $218-E-12 A$ & Trenches & $8.9 \times 10^{4}$ & $1.5 \times 10^{3}$ & 8.93 & 55 & Active \\
\hline $218-E-12 B$ & Trenches & $4.6 \times 10^{4}$ & $1.3 \times 10^{5}$ & 1.27 & 1,790 & Active \\
\hline $218-E-14$ & Tunne? & $2.0 \times 10^{3}$ & $5.7 \times 10^{2}$ & NA & 5,020 & Inactive \\
\hline $218-E-15$ & Tunne] & $1.0 \times 10^{4}$ & $5.4 \times 10^{2}$ & $<.500$ & 2,200 & Active \\
\hline
\end{tabular}

NA - Data Not Available 
TABLE IV

SOLID RADIOACTIVE WASTE STORAGE AND BURIAL SITES 200 WEST

\begin{tabular}{|c|c|c|c|c|c|c|}
\hline Number & Type & $\begin{array}{l}\text { Area } \\
\text { (Sg. m.) }\end{array}$ & $\begin{array}{l}\text { Waste Vol. } \\
(\mathrm{Cu} \text {.m.) }\end{array}$ & $\mathrm{Pu}, \mathrm{Kg}$ & $B, \gamma C i$ & Status \\
\hline $218-W-1$ & Trenches & $2.1 \times 10^{4}$ & $7.0 \times 10^{3}$ & 94 & 8.4 & Inactive \\
\hline $218-W-1 A$ & Trenches & $3.8 \times 10^{4}$ & $1.6 \times 10^{4}$ & 2 & 2,100 & Inactive \\
\hline $218-W-2$ & Trenches & $2.8 \times 10^{4}$ & $8.2 \times 10^{3}$ & 126 & 24 & Inactive \\
\hline $218-W-2 A$ & Trenches & $8.1 \times 10^{4}$ & $1.9 \times 10^{4}$ & 6.4 & 13,300 & Active \\
\hline $218-W-3$ & Trenches & $3.7 \times 10^{4}$ & $1.1 \times 10^{4}$ & 68 & 48 & Inactive \\
\hline $218-W-3 A$ & Trenches & $5.9 \times 10^{4}$ & $2.4 \times 10^{4}$ & 16 & $4.4 \times 10^{5}$ & Active \\
\hline $278-W-4 A$ & $\begin{array}{l}\text { Trenches, } \\
\text { Caissons }\end{array}$ & $6.6 \times 10^{4}$ & $1.8 \times 10^{4}$ & 35 & 199 & Active \\
\hline $218-W-4 B$ & $\begin{array}{l}\text { Trenches, } \\
\text { Caissons, } \\
\text { Asphalt Pad, } \\
\text { Vee Trench }\end{array}$ & $4.2 \times 10^{4}$ & $1.0 \times 10^{4}$ & 45 & $1.56 \times 10^{5}$ & $\begin{array}{l}\text { Active } \\
\text { Active } \\
\text { Active } \\
\text { Inactive }\end{array}$ \\
\hline $218-W-4 C$ & $\begin{array}{l}\text { Trenches, } \\
\text { Asphalt Pad }\end{array}$ & & & & & $\begin{array}{l}\text { Active } \\
\text { Active }\end{array}$ \\
\hline $218-W-7$ & Vault & 23 & $1.6 \times 10^{2}$ & $<0.001$ & 205 & Inactive \\
\hline $218-W-8$ & Vault & 23 & 2,400 & $<0.001$ & 33 & Inactive \\
\hline $218-W-9$ & Trenches & & 68 & NA & NA & Inactive \\
\hline
\end{tabular}

NA - Data Not Available 


\section{TABLE V}

SOLID RADIOACTIVE WASTE STORAGE AND BURIAL SITES

$$
300 \text { - } 600 \text { AREAS }
$$

\begin{tabular}{|c|c|c|c|c|c|c|}
\hline Number & Type & $\begin{array}{l}\text { Area } \\
\text { (Sq.m.) }\end{array}$ & $\begin{array}{l}\text { Waste Vol. } \\
(\text { Cu.m.) }\end{array}$ & $\underline{\mathrm{Pu}, \mathrm{Kg}}$ & $\underline{B, \gamma C i}$ & $\begin{array}{l}\text { Depth to } \\
\text { Water } \\
\text { Table (m. }\end{array}$ \\
\hline $318-1$ & Trenches & $4.5 \times 10^{3}$ & NA & NA & Trace & 12 \\
\hline $318-2$ & Trenches & $7.0 \times 10^{3}$ & NA & NA & 0 & 12 \\
\hline $378-3$ & Trenches & $5.4 \times 10^{3}$ & NA & NA & 0 & 4 \\
\hline $318-4$ & Trenches & $1.2 \times 10^{4}$ & NA & $N A$ & 0 & 10 \\
\hline $318-5$ & Trenches & $5.0 \times 10^{4}$ & $N A$ & NA & 0 & 12 \\
\hline $318-7$ & Pits & $6.8 \times 10^{4}$ & NA & NA & 0 & 16 \\
\hline $318-8$ & Trenches & $5.6 \times 10^{4}$ & $N A$ & NA & 0 & 16 \\
\hline $318-9^{(1)}$ & Trenches & $2.6 \times 10^{2}$ & $3 \times 10^{3}$ & NA & & 17 \\
\hline $318-10^{(2)}$ & Trenches & $2.5 \times 10^{4}$ & $N A$ & NA & NA & 20 \\
\hline $318-11^{(3)}$ & Trenches & $3.5 \times 10^{4}$ & NA & $<0.7^{(4)}$ & $<2,000$ & 88 \\
\hline $272-N$ & Building & & $2.2 \times 10^{2}$ & $\sim .04$ & & \\
\hline
\end{tabular}

NA - Data Not Available

(1) Also known as 300 West Burial Site

(2) Also known as 300 North Burial Site

(3) Also known as 300 Wye Burial Site

(4) Records are not certain; this quantity may be on the order of 5 kilograms 
STORAGE AND BURIAL QUANTITIES

FY 1976

Location

TRU Waste

TRU Pad

TRU Caisson

TRU Trench Total TRU
Cu.m.

$2.5 \times 10^{2}$

1.6

$\frac{5.9 \times 10^{2}}{8.4 \times 10^{2}}$

NonTRU Waste

Caisson

Trench

Total NonTRU

Total Waste
1.7

$\frac{4.6 \times 10^{3}}{4.6 \times 10^{3}}$

$5.4 \times 10^{3}$
. $\mathrm{Pu}, \mathrm{Kg}$

$2.04 \times 10^{3}$ $.43 \times 10^{2}$

$\frac{2.8 \times 10^{3}}{5.3 \times 10^{3}}$

1.1

$3.4 \times 10^{3}$

$\frac{0}{3.4 \times 10^{3}}$

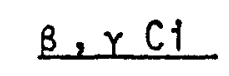


FACILITIES AND PRACTICES

TRU WASTE RETRIEVABLE STORAGE

Asphalt Pad

Asphalt pads are currently being used for 20 year retrievable storage for solid low level TRU wastes. The wastes are packaged in 55-gallon drums or in steel boxes with 20 year service life expectancy, then stacked on the pad in $7.3 \mathrm{~m} \times 7.3 \mathrm{~m} \times 3.7 \mathrm{~m}$ high modules, (Figure XIX). Flame retardant $1 / 4$-inch plywood is placed between the layers and $3 / 4$-inch plywood on top of the modules. The completed module is covered with ore ounce PVC laminated nyton sheet, and 1.3 meters of earth overburden. Modules are separated from each other by $1 / 3$ meter of earth. Two 2 -inch diameter pipes extend from near the bottom inside the module to about one meter. above the soil caver to permit sampling of the atmosphere inside the storage module. The approximate ratio of waste volume to land area is $6.6 \times 10^{6} \mathrm{~m}^{3} / \mathrm{m}^{2}$.

Each drum and box is marked with an identifying number, which is noted also on the burial records. Thus, the contents and location of each package is known. Drums or packages which have any combustible material, besides the packaging materials (the drum liner), are identified as "combustible" and are painted black. Drums with noncombustible contents are red or white. Since 1970 about $90 \%$ of the wastes have been classified "combustible". Combustible and noncombustible wastes have been stacked together because it was felt to be impractical to isolate the $90 \%$ combustible from the $10 \%$ noncombustible.

A crane with cable sling is used to stack the storage drums and boxes in position on the pad. The planned method of retrieval is by removing the soil overburden, plastic sheet and plywood covers, then lifting out the boxes and drums with a crane.

While this facility is expected to provide the protection necessary for retrievable 20 year storage of wastes after it is finally covered with the earth fill, the packages in uncompleted modules are exposed to wind, blowing sand and precipitaion. Drums are handled and placed in position with a wire rope sling and crane which as resulted in damage to the protective coating (paint) on the drums. The addition of weather protection and improved handling equipment would provide greater assurance of meeting the 20 year retrievable storage requirements.

"Vee" Trench

A prototype concrete "Vee" Trench was constructed and filled with 55-gallon drums of waste from June 1972 to March 1973 as illustrated in Figure XX. Waste drums were laid at a $45^{\circ}$ angle in the "Vee" trench compartment. A steel cover was then placed on the compartment and covered with four feet of earth overburden. Air sampling pipes were provided. The planned method of retrieval is to remove the overburden, lift off the steel cover plate, then remove the drums with a boom crane and cable sling or drum hook. The 


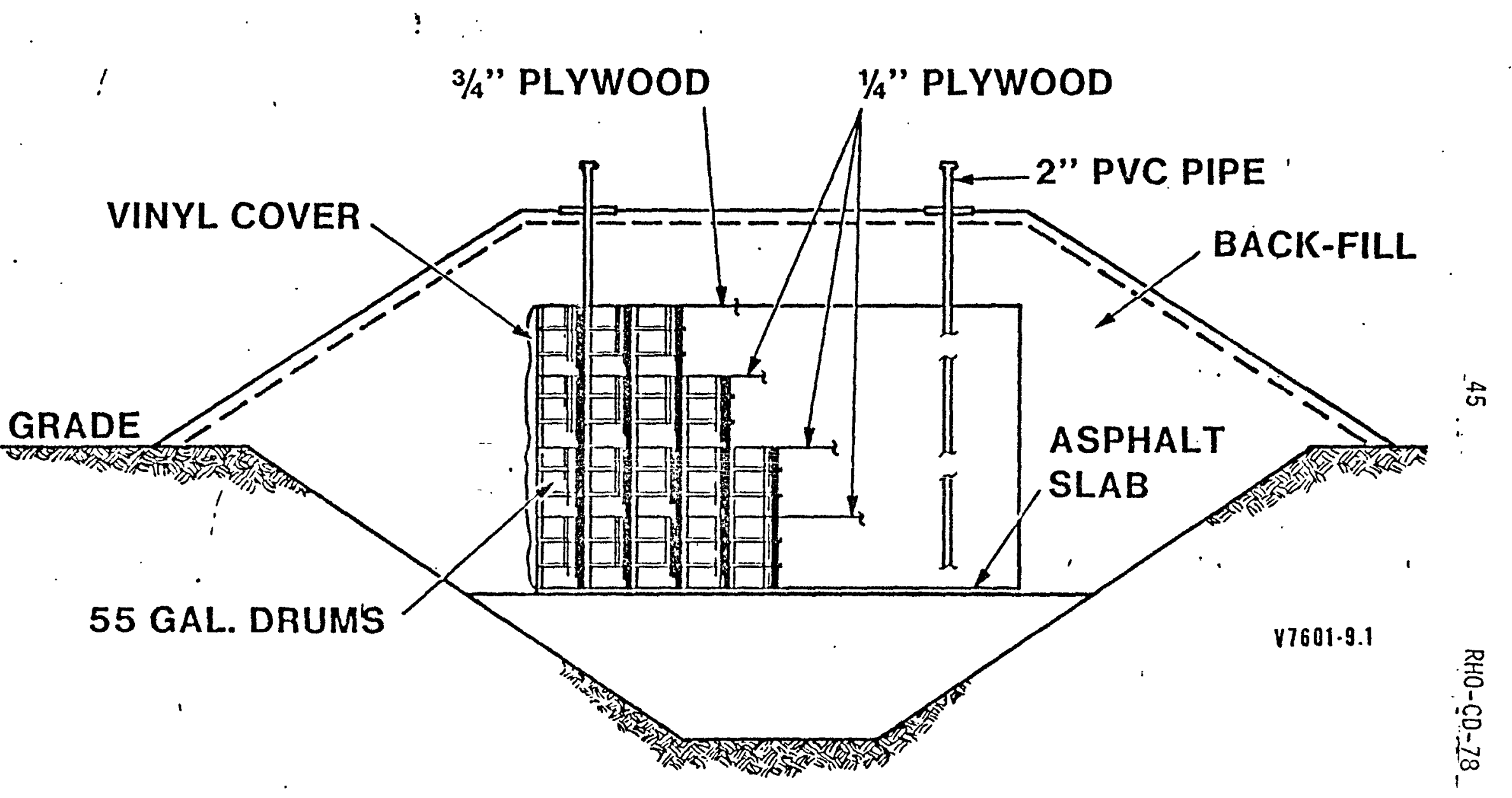

FIGIURE XIX

ASPHALT PAN TRII STORAGE 

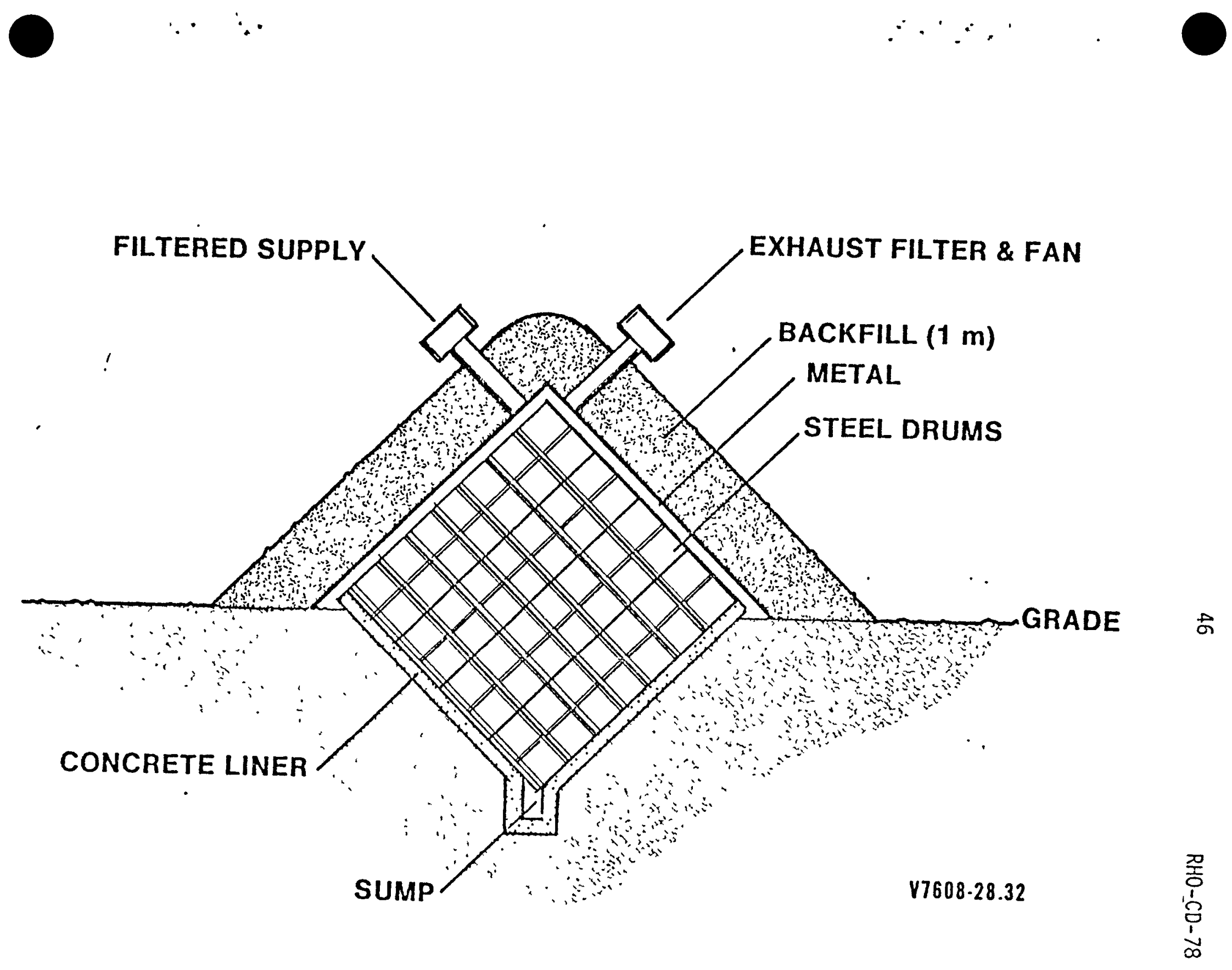
drums are expected to survive a 20 year life in the Hanford environment.

The "Vee" trench is considerably more expensive than the asphalt pad and does not provide significant advantages; consequently no additional "Vee" trenches are planned.

\section{Caisson Storage}

Underground caissons are used for storage of small packages of TRU waste with high activity level. The waste is packaged in one gallon or five gallon paint cans with clips or resin to hold the lids in place. The caissons are reinforced concrete cylinders turied $>4.0 \mathrm{~m}$ below grade, as shown in Figure XXI. The calssons have .9 meter (3fejet) diameter inlet chutes, offset or convoluted to block the "shine" from the radioactive contents. The caissons are provided with exhaust systems fitted with HEPA filters and electrically driven exhausters, which are operated to provide a down draft through the inlet chutes into the caisson while the caissons are being charged. Packages of waste are brought to the caisson site in truck mounted shielding casks. The cask is positioned over the caisson and the gate on the bottom of the cask is opened allowing the waste package to fall into the caisson.

Waste packages are allowed to fall freely into the caissons, which results in damage and, at times, rupture of the packages in the caisson. Also the present facilities are in the open, without weather protection, which prohibits disposal operations during adverse weather conditions. Weather shelters are presentiy being designed to correct this problem. Although current caisson placement has resulted in poor land economy, future caissons can be installed closer together to improve land utilization.

Retrieval is based upon removal of the entire caisson, which is quite large and deeply buried, to a suitable processing location. The caisson is not designed for transportation and a receiving facility has not been identified, therefore, retrieval and repackaging will be very expensive. A new caisson storage concept addressing these deficiencies is needed.

Purex Railroad Tunnel Storage

Extremely large, heavy or highly contaminated waste equipment is stored on railroad flat cars in two railroad tunnels which are connected to the Purex Building canyon as shown on Figure XXII. The contamination may be TRU or nonTRU. One tunnel is filled with eight flat cars and is now inactive. The second tunnel is available for use. It is $515 \mathrm{~m}$ long and can store about 42 flat cars, depending on length. Nine cars of waste are now in storage in this tunnel. The Purex tunnel is considered adequate for the interim storage of wastes. Additional room is available for a large quantity of waste.

TRU Trenches

Some TRU waste is unsuitable for pad or caisson storage because of size, security requirements or surface radiation. This waste is packaged in fiber glass reinforced polyester covered plywood boxes, reinforced concrete boxes, 


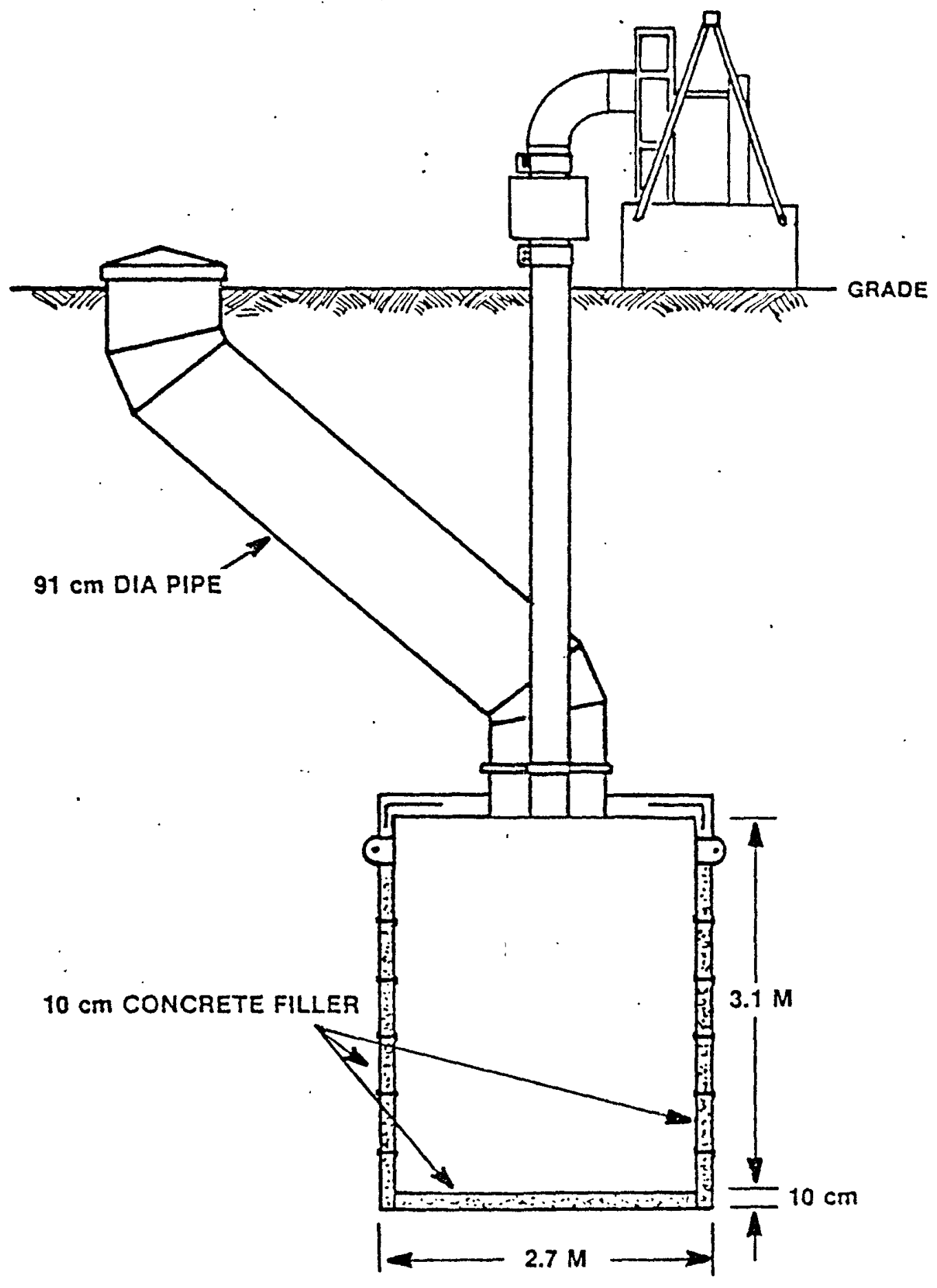

FIGURE: XXI

CAISSON TRU STORAGE 


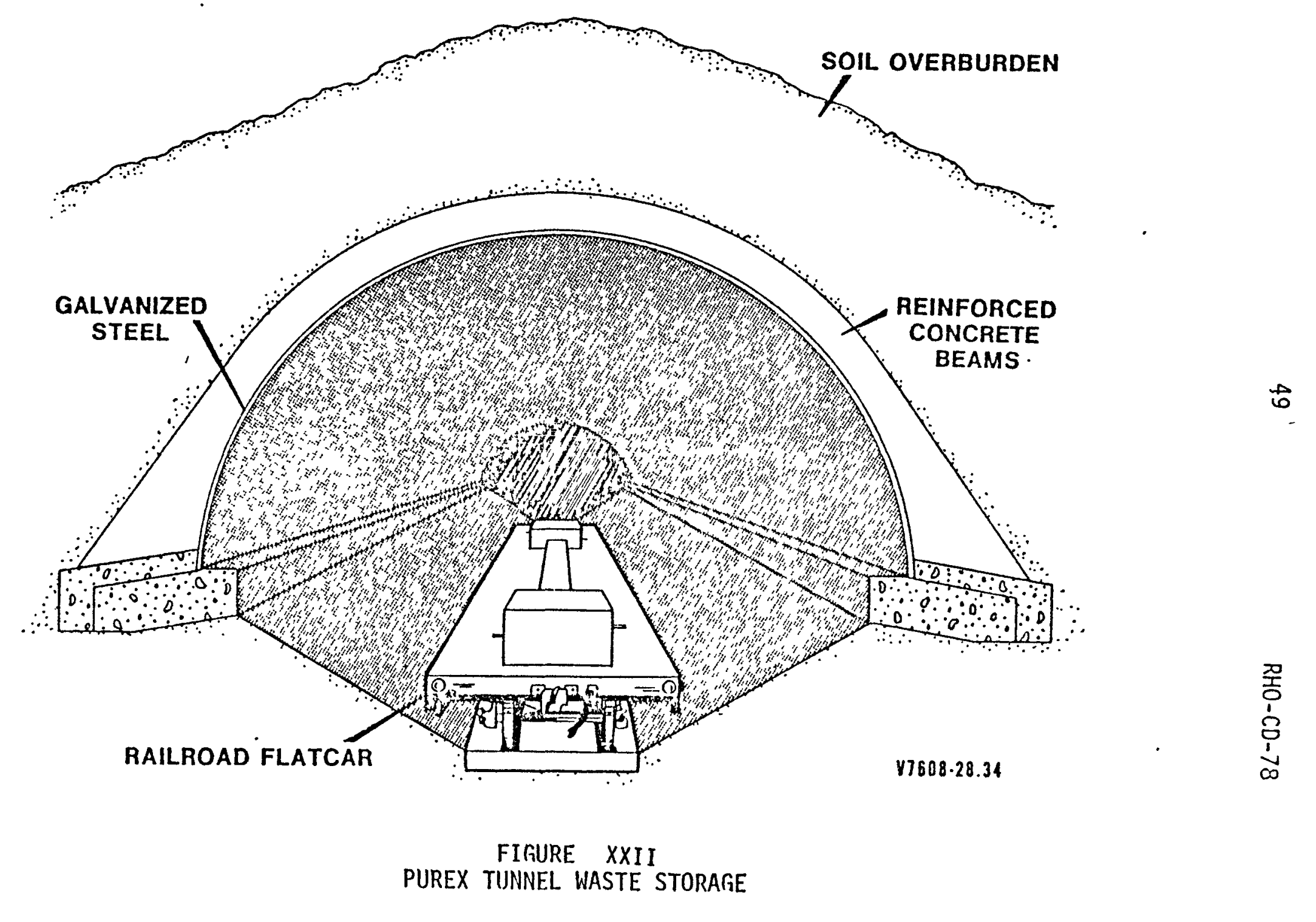


metal boxes or 55-galion drums and buried in specially designated alpha trenches. Typical alpha trench design is similar to Figure XXIII, except that, normally, only one meter of earth cover is required. The packages are expected to meet 20 year retrievable storage criteria in this service.

The alpha trenches are also used for storage of TRU and nonTRU classified waste, usually in 55-galion drums. The drums are currently stacked vertically; plywood is placed on top of each layer of drums. The drums are then covered with PVC laminated nylon sheet and four feet of earth. The classified wastes are covered on the day they are received to satisfy security requirements.

NONTRU BURIAL

Burial Trenches

Burial trenches, typically represented in cross section in Figure XXIII, have been used for nonTRU wastes since startup. These are referred to as "industrial trenches" when used for disposal of physically large contaminated items (usually failed plant equipment) and "dry waste trenches" when used for other contaminated materials.

The trenches are used for a variety of waste, including but not 1 imited to low level waste in sealed cardboard boxes, 55-gallon drums, specially fabricated wood, metal and reinforced concrete containers and failed equipment both boxed and direct buried. Burial trenches are normally closed by backfilling with a minimum of eight feet of earth cover to the same level as the surrounding surface. The trenches are not sealed. Burial trenches provide an economical and adequate method of waste disposal.

Land use per unit volume of waste, however, is relatively high for these reasons: (1) trench sides are sloped at about 45 degrees which is the natural angle of repose of the Hanford soil; (2) most wastes are not compacted before burial, but are compressed in place by the weight of the earth and the earth moving equipment; (3) the practice of covering all waste by nightfall results in wasting a considerable volume of otherwise available space in the trench.

Caissons (SiTos)

Buried caissons, sometimes called silos, are used for high activity nonTRU waste. A sketch of a typical caisson is shown on Figure XXIV. In contrast to the TRU storage caissons, these nonTRU burial caissons are not designed for retrievability; they are constructed of vertical 2.4 meter diameter corrugated metal cyclinders with concrete slabs closing both ends. They have .9 meter ( 3 ; feet) diameter inlet chutes, offset or convoluted to block radiation "shine". Exhaust systems with electric exhausters and HEPA filters are included to provide a down draft into the calsson while wastes are being charged. 


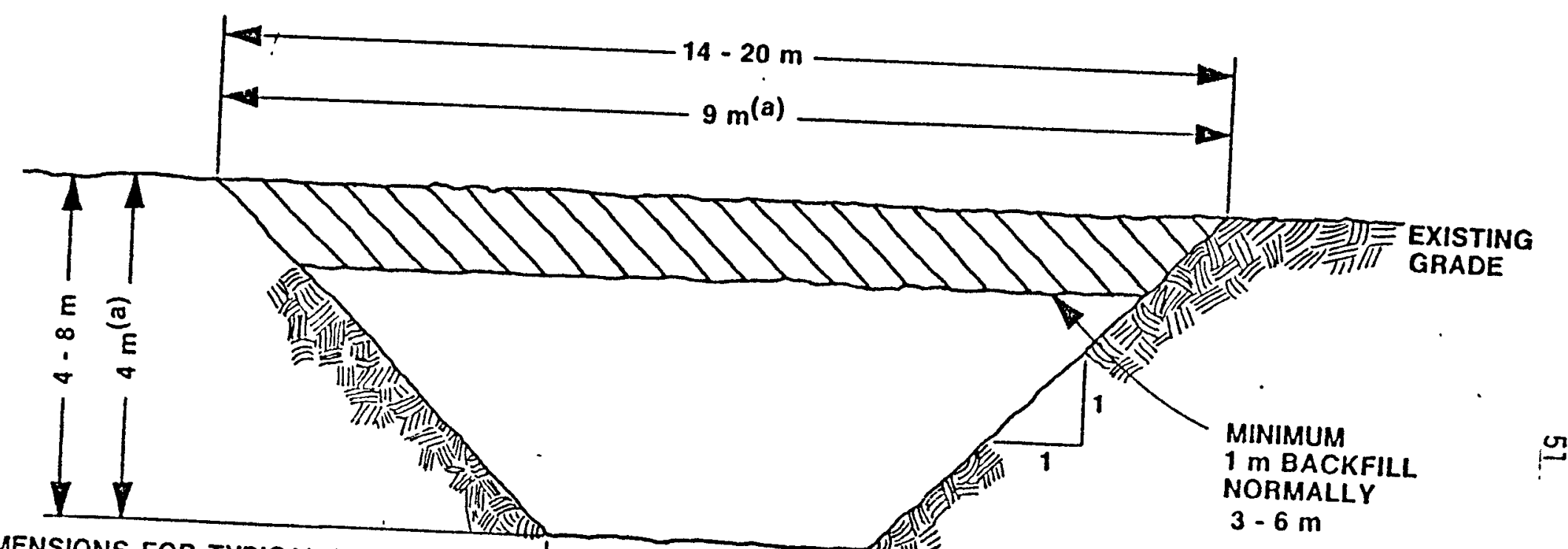

(a) DIMENSIONS FOR TYPICAL "DRY WASTE" TRENCH; CARDBOARD BOXES, BARRELS, CONTAMGER DIMENSIONS ARE FOR WASTE TRENCH "INDUSTRIAL" SOLID WASTE TRENCH; FAILED PROCESS EQUIPMENT IN LARGE METAL OR CONCRETE BOXES)

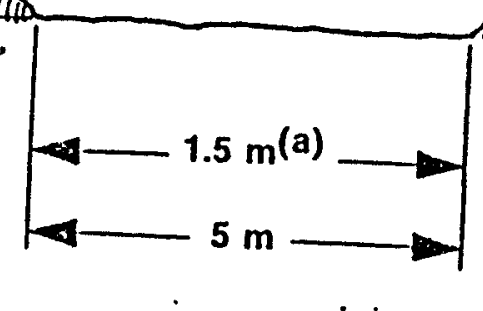




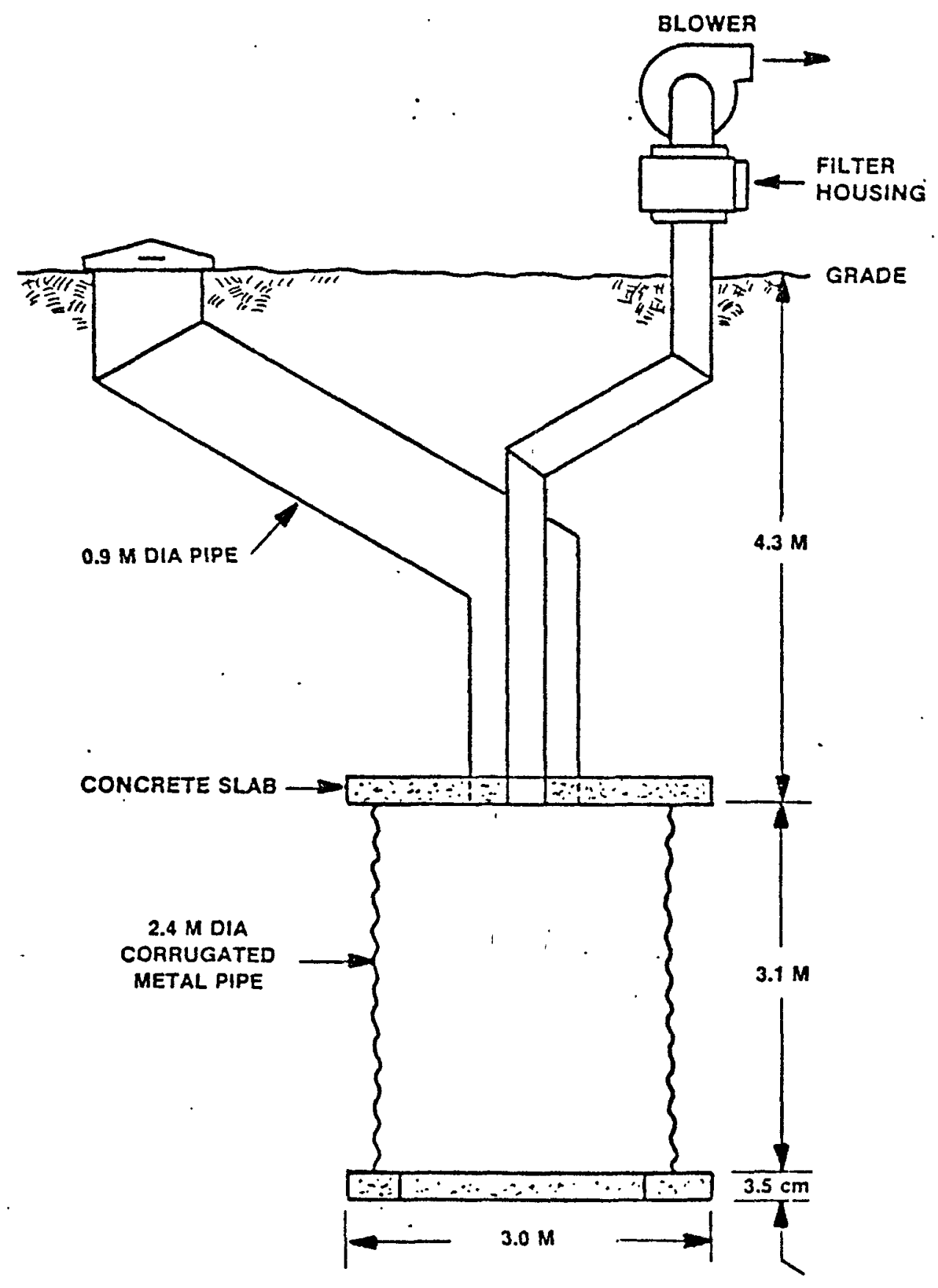

\section{FIGURE XXIV}

NON TRU SOLID WASTE BURIAL CAISSONS 
Caisson wastes are delivered to the site in truck mounted shielding casks, packaged in 5-gallon paint cans. Small metal parts with induced activity such as fuel element clips and spacers, are charged directly, without packaging, into the caisson. Separate caissons are provided for the packaged and nonpackaged wastes.

\section{Other Disposal Facilities}

Other types of specialized disposal facilities have been used for specific purposes:

Crib pits, $2.7 \mathrm{~m}$ square, constructed of railroad ties, were used for small reactor hardware.

Vertical steel pipes and culverts, various diameters, for small parts.

Pipe storage units made by welding together five 55-gallon drums.

A concrete block building containing boxes of contaminated equpment. (The boxes are covered with vermiculite for fire protection)

Buried vaults constructed of vertical cylindrical concrete culvert sections, for laboratory wastes.

These facilities are now retired. Further use of facilities of these types is not expected with the waste types currently being handled.

\section{WASTE PROCESS̈ING}

\section{Packaging}

With the exception of TRU waste packaging, which must remain in retrievable condition in storage, for a 20 year period, all other packaging is provided only for protection of personnel and the environment during shipping and handling. Protection of nonTRU waste is not required after burial. Packaging and transportation are, therefore, closely related. ERDÁ Nianual Chapter RL Appendix 0529 (5) establishes policy by stating "Radioactive Material shall be prepared, packaged and transported in a safe manner such that the transport will not present a hazard to the health and safety of the plant personnel or to the public." An equivalent degree of safety should be provided for onsite shipments as is afforded by the shipping regulations adopted by the Department of Transportation. It is RL's policy to use DOT approved containers whenever technically and economically practicable for onsite shipments and to keep the exposure to individuals during the transportation and handling of material packages as low as practicable. 
DOT approved containers are not considered technically or economically practicable for much of the radioactive wastes handled at Hanford. For this reason, mechanisms are established by ERDA-RL Appendix 0529 and ARH-MA-101 (6) for approval of the use of nonDOT approved packages by ascending levels of authority, depending upon the type and quantity of contamination and whether the movements are between or completely within the designated operating areas. A "Package Review Board" has been set up within Rockwell as outlined in ARH-MA-101. Figure XXV, "Package Review Flowsheet", summarizes the approval system.

Currently used packaging for radioactive wastes ranges from cardboard boxes sealed with tape to specially engineered flanged steel containers with reinforced concrete shielding. Department of Transportation (DOT) approved 55-gallon drums are used for both TRU storage and nonTRU burials. Specially designed burial boxes are made, as needed, of reinforced concrete, metal or fiberglass reinforced polyester covered wood. Engineering and fabrication facilities are available for designing and constructing adequate packaging. Fabrication costs can be high; new and cheaper disposal containers need to be considered where possible.

Compaction

Compaction is practiced on only a small fraction of Hanford wastes. The following compaction facilities are currently in use:

A Sears, Roebuck and Company residential type garbage compactor, in the 200 West Area and Gladco Series C, Type 6 Refuse compactor, in the 300 Area, are used to compress laboratory wastes. These wastes are paper, cardboard cartons, packaging, etc., which are not known to be contaminated but have been in an area where radioactive materials are handled. Both units are hooded. The quantity of compacted waste is small.

A hooded drum compactor is used to compress paper towe1s, trash, etc., from a change room in the 200 West Area. They are compressed into a 55-gallon drum.

Highly contaminated plastic sample bottles are melted, with a heat lamp, into one pound metal lard cans in the 222-5 (200 Area) laboratory.

A prototype facility to reduce the volume and size of discard (100 Area) reactor fuel element spacers is scheduled for FY 1978. This unit will cut and crush the spacers into small pieces for more efficient handling and disposal.

Incineration and Acid Digestion

An incineration facility was operated from 1963 to 1972 for the purpose of recovering plutonium from combustible scrap. This unit handled about six to seven pound of scrap per hour. This unit is not considered suitable for further use because it was too expensive to operate, a large expenditure would be required to refurbish it, and primarily, it has basic design deficiencies. 


\section{PACKAGE APPROVAL FLOWCHART}

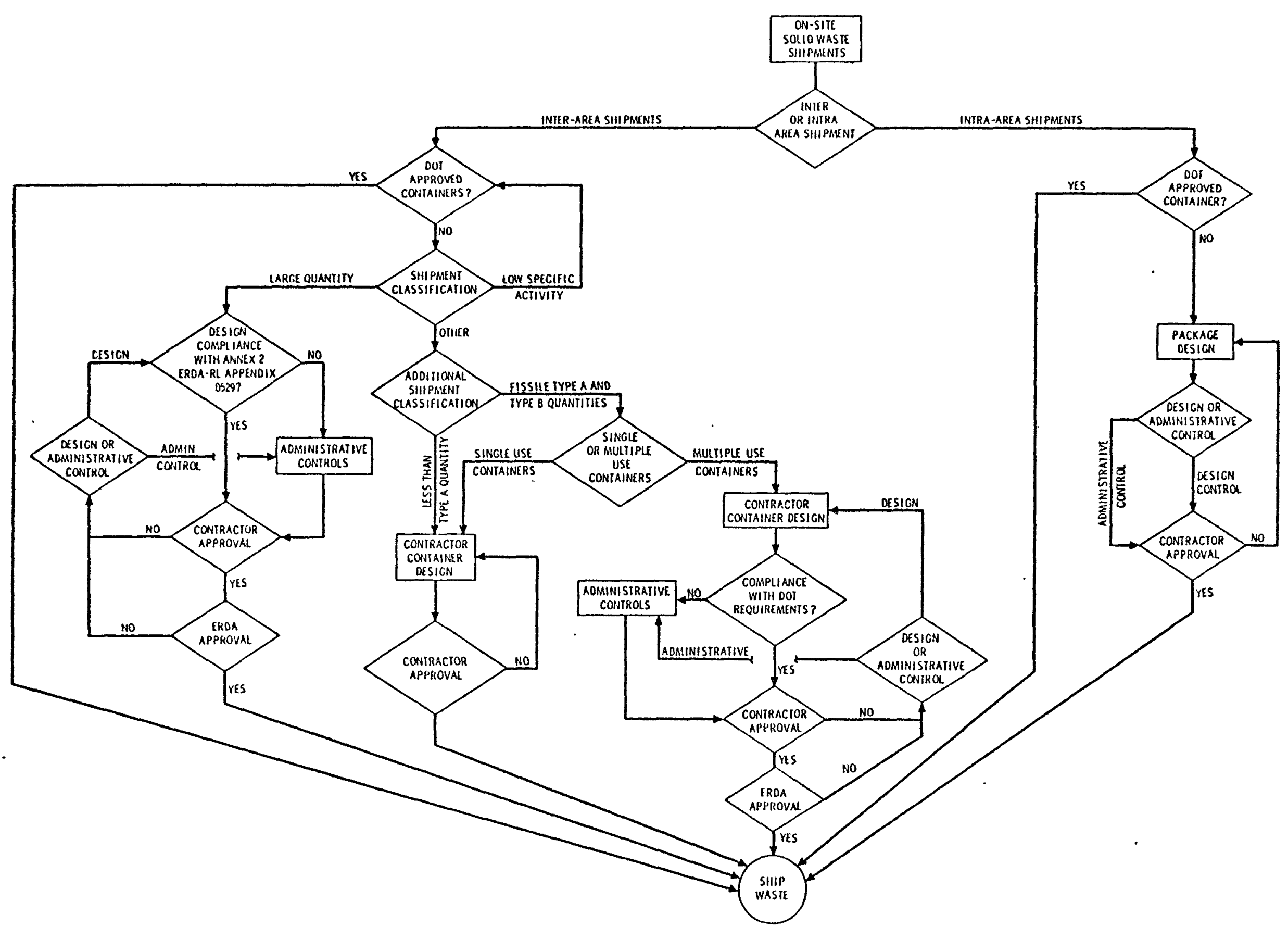


A demonstration acid digestion facility for TRU combustible wastes is now under construction which will decompose combustible wastes in hot $\left(250^{\circ} \mathrm{C}\right)$ concentrated sulphuric acid solution followed by further oxidation with nitric acid. Cold testing is scheduled to begin late in FY 1977 followed by hot testing in FY 1978. Further evaluation will be necessary to determine whether this unit can be adapted to economical routine TRU waste volume reduction.

\section{TRU Segregation}

Since 1970, AEC and ERDA regulations have required the storage of materials containing over $10 \mathrm{n} \mathrm{ci/g} \mathrm{TRU} \mathrm{nuclides} \mathrm{in} \mathrm{such} \mathrm{a} \mathrm{manner} \mathrm{that} \mathrm{they} \mathrm{can} \mathrm{be}$ retrieved in packages free from surface contamination for a 20 year period. Three basic methods are used to determine whether waste packages should be placed in 20 year retrievable storage:

Determination by assay. Waste packages are "counted" or measured by "Segmented Gamma Scan Assay System" (SGSAS), sodium iodide (NaI) or other assay methods to determine whether they meet the $10 \mathrm{n} \mathrm{ci} / \mathrm{g}$ criterion.

Determination by source. All wastes from certain areas known to contain TRU radionuclides are considered to be potentially contaminated and are placed in TRU storage.

Determination by Material Balance Calculation. In certain cases where the amount of contamination and the total waste quantity are accurately known, material balance calculations are used to determine whether the waste meets the $10 \mathrm{n} \mathrm{ci/g} \mathrm{criterion.}$

\section{SUPPORT FACILITIES AND SERVICES}

\section{Fire Protection}

Hanford has three fire stations manned on a 24 hour basis. Each station is equipped with the following:

2 - 750-gallon per minute pumper engines

2 - 1200-gallon 4-wheel drive spray trucks for grass fire control

One 3000-gallon supply truck is available on the site to service the other trucks.

All of the Hanford storage and burial grounds are within an eight mile distance from the closest fire station.

Utilities: Power, Water, Telephone

Solid waste storage and burial facilities are a small part of the overall Hanford operations. Hanford utility systems for power, water and telephone are quite extensive and are avilable for use for the solid waste storage and burial activities. 
Offices, Change Rooms, Decontamination Facilities

Office, change room and decontamination facilities are shared with other Hanford operations. Adequate facilities are available in both 200 East and 200 West Areas, locations of the currently active storage and burial sites.

\section{Security, Lighting, Fences}

About one third of the burial grounds in the 100 Areas are within security fences. All burial grounds in the 200 Areas lie within the perimeter fences of their respective areas and, in addition, burial ground $218-4-4 B$ which contains TRU waste in 20 year storage is surrounded by an additional fence. All of the 300 Area burial grounds except 318-1 lie outside the 300 Area perimeter fence; these are fenced separately, except 318-8 which 1 ies under a paved parking lot. The 200 and 300 Area perimeter fences are lighted.

Roads, Railroads, Transportation,

The Hanford Project has an extensive road and railroad network, suitable for al1 needed types of vehicles and equipment. A11 storage and burial grounds are serviced by roads; all currently active burial sites are accessible to railroad transport.

Special arrangements, such as providing radiation monitoring and patrol escorts, can be made when necessary.

\section{Equipment}

Handling equipment available for solid waste include:

Trucks with installed shielding casks, used for transporting high dose rate packages for storage in the caissons.

Flat.bed trailers, 44 foot and 60 foot long, for transporting contaminated equipment.

Hydraulic and mechanical motor cranes for handling drums, large boxes and heavy equipment.

Standard trucks for transporting boxed dry wastes.

Fork lift trucks.

Earth moving equipment used for opening and closing trenches, installing caissons and other earth work includes:

One 60-ton boom crane with drag clam shell bucket.

Earth movers.

Crawler tractors.

Self-propelled cranes, 20-ton and 25-ton capacities.

Frontend loaders. 
Additional equipment is available from other contractors on the Hanford site or in the eastern Washington area. Equipment coverage is adequate for forseen requirements.

\section{Disposal and Storage Site Maintenance}

Monthly or semiannual physical and radiation surveys are made of all 100 , 200, and 300 Area burial sites. The physical survey investigates for undesirable weed growth, burial ground cave-ins, soil errosion, damaged radiation postings, boundry markers and fencing, damage caused by wild life and any other undesirable changes that may have occurred since the previous survey. The radiation survey includes burial ground monitoring for activity level (The burial ground allowable dose rate is one millirem.per hour three feet above ground leve1), loose contamination, contamination spread and radioactivity uptake in plant life.

The survey results are reported to the area custodians: United Nuclear Industries for the 100 Areas and Rockwell Hanford Operations for 200, 300 and 600 Areas burial sites.

Routine work performed to maintain the integrity of the burial grounds include filling slumps, maintaining surface contours, removing deep rooted plants (soil sterilants are used in the 100 Areas) and other necessary jobs.

Nuclear Safety and Criticality Control

The fissile content of each container accepted for burial is determined at the time, or subsequent to, packaging, and the amount of fissile material is entered on the shipping papers. The determination is made either by chemical analysis of a sample of the material in the package, by nondestructive analysis (NDA) of the package contents, or by material balance at the generating facility. The NDA equipment used to measure the fissile content is either a sodium iodide counter or a segmented gamma scan assay system.

Criticality Prevention Specifications (CPS) have been written specifically for disposal of fissile material. For example, 55-gallon drums are limited to 200 grams of fissile material. Any package with a greater fissile material content than the limit requires review and approval before it can be accepted for storage. Preparation of the new CPS involves an evaluation of the criticality potential for the particular package and the array into which the package will be placed. An alternative to preparing a new specification for a drum with greater than 200 grams fissile material is to repackage the drum with less than 200 grams of fissile material.

Criticality Prevention Specifications also limit the amount of fissile material to 175 grams per square foot of area in the burial/storage area. This limit determines the height of the packages in the array based on the fissile material content of the containers.

Control limits set by the Criticality Prevention Specification are implemented by the operating group in charge of the burial operation. Key to the safety 
of the operation is the information in the shipping papers which provides the quantity of fissile material in each package or container.

\section{Monitoring}

A11 of the wastes are monitored at their point of origin. Dose rates at the surface of package are determined and recorded on the Sol id Waste Burial Record and Radioactive Shipment Record to accompany the solid wastes. All packages must be free from external contamination. An estimate of the radioactive inventory in the waste container is also recorded.

Generally radiation rates at the surface of each waste package are less than $10 \mathrm{mR} /$ hour. "Hotter" wastes are separated to reduce radiation dose rates to personnel. High activity wastes are transported in shielded metal containers and are loaded on the truck so as to keep dose rates to the driver to less than $6 \mathrm{mR} /$ hour unless the trip is of very short duration. Activity levels at the sides and tailgate of the truck are controlled to less than $50 \mathrm{mR} /$ hour. Escort and monitoring to the burial site is required for waste loads exceeding the above limits. All burial work is done under constant monitoring by Radiation Monitoring personne?

Surveillance of the burial sites is handled by Radiation Monitoring personnel working in conjunction with Environmental Protection engineers. Frequency of audits range from monthly to semiannually, depending on the site.

All burial grounds have perimeter markers. Ambient air samplers are located so as to detect resuspension of radioactive particulate matter from the surfaces of the burial grounds.

PERSONNEL

Training

All employees receive training prior to being assigned to burial ground operations. This training is conducted by a supervisor or an assigned individual qualified to do so. Such items as radiation protection, protective clothing and equipment, proper lifting methods, and equipment operation are covered.

Burial operations are performed in accordance with Standard Operating Procedures (SOP's). Procedures contain specific instruction relative to the activity being performed. All burial operations are done under constant radiation monitoring surveillance. Both operations and heavy equipment supervision are available.

\section{Safety Programs}

Safety requirements for the operation of the Burial/Storage Grounds are based on the requirements and standards set forth in the ERDA Manual 0500 series. Pertinent material from these and other Safety and Health Standards are the basis for the safe operation of the burtal ground facilities. 
The "ARHCO Accident Prevention Standards" (Reference 7) summarizes such items as Personnel Training and Safety Meetings, Administration of Safety Rules, Accident Reporting, Personal Protective Equipment, Working with Railroad Cars, Excavation, Trenches, and Shoring. In addition to these general standards, a set of Master Safety Rules are provided.

EMERGENCY PLANNING

The overall responsibility for the protection of personnel and property associated with solid waste burial, as described in the "Emergency Procedures" Manual, (Reference 8), rests with the Manager, Tank Farm Operations. This responsibility includes the establishment and documentation of emergency planning. Emergency plans for solid waste burial are addressed both in the Standard Operating Procedures (SOP's) and the Emergency Procedures (Refer:ence 8) for Tank Farm Operations.

Operations and Radiation Monitoring are equipped with emergency equipment for use with solid waste burial. A caravan enroute to the burial grounds displays flashing yellow warning lights on the vehicle carrying the material and/or accompanying safety vehicles. The accompanying Operations vehicle carries these emergency items: A radio for communication, ropes, radiation zone signs, red safety cones, portable reflecting red safety lights, and other material necessary to block off an area, a fire extinguisher and plastic for contamination control, etc. Additionally, monitoring equipment inciuding a Geiger-Mueller Counter, and alpha detection instruments, along with extra protective clothing, copies of radioactive shipment record, surveys, etc., are carried by the Radiation Monitoring vehicle.

In the event of an emergency, Operations supervision and Radiation Monitoring are immediately notified by radio. In the event of a contamination release or accident (or stalled vehicle) enroute to the burial grounds, the caravan including Patrol and Radiation Monitoring vehicles is stopped immediately. The area is roped off and tagged with radiation zone signs to prevent others form receiving exposure. Emergency lights or safety cones may be set up to warn traffic, depending on the situation. Personnel-are required to stay with the transporting vehicle until released by Operations supervision.

\section{RECORDS}

As stated earlier, very few records were kept of either classified or unclassified material before 1960. During the period from 1960 through 1967 , records which reported the source and volume amount of all waste buried were kept and provided to the Atomic Energy Commission. Although these records identified the burial ground in which the waste was buried, specific coordinates for each burial were not recorded, and classified burials were not differentiated from unclassified burials.

Since 1968, records of land area used, the volume of waste, the curies of the specific nuclides and the coordinates of the burial have been maintained for all material buried in the 200 Areas. In some cases, documentation exists which identifies the buried material as classified; however, particularly in 
the case of material originating at Hanford, such information is not always contained in burial records.

At the present time, all solid wastes are accompanied by "Solid Waste Burial Record" form \#54-3000 (3-77) and "ARHCO Solid Waste Burial Record" form "I54-6500-028 (3-77) when shipped to the burial grounds for disposal. A Transuranic Dry Waste Storage form must also accompany the shipment if transuranics are included in the waste. Upon receipt ot the waste shipment at the burial ground, the "Disposal Site" section of the Solid Waste Burial Record and the Transuranic Dry Waste Storage forms are completed. These sections show the date of burial, the burial ground utilized, the trench number and coordinates of the burial.

Following burial of the waste, these forms (except the classifed forms which are kept in a locked safe) are compiled with other burial forms and corresponding shipping papers into binders, each covering a three month period. Binders are retained for a specified length of time in a fireproof repository. After an appropriate storage period in the office files, the binders are transmitted to the ERDA Records Holding Area for long-term indefinite storage.

Starting fiscal year 1977, Hanford has been participating in the "Solid Waste Information Management System" (SWIMS) program. Under this program, complete data on all solid waste to treatment, storage and burial are reported quarterly to the regional (Idaho) data collection office. Information reported includes nuclide description, quantities, concentration, treatment and operating costs. This information is then stored in a data bank for access by authorized offices.

Accidents and contamination spreads are reported on serialiy number "Occurrence Report" forms. Reports on a11 accidents and spills to date are periodically published.

Vehicle and equipment monitoring records are documented and filed in accordance with "Environmental Surveying and Sampling Documents," ARH-MA-143. This is an audited program for the maintenance of permanent records. 
MONITORING AND CONTROL OF RADIOACTIYITY

The environmental characteristics of the Hanford Reservation are generally favorable for safe shallow land burlal of solid radioactive wastes. The major factors identified in the assessment are (a) limited rainfall, (b) high solar heat input (which results in a high moisture deficiency in the soi1), and (c) depth to the underlying water table.

Three studies are needed to substantiate these environmental safety factors in the currently active 200 Area. First, an evaluation of the $218-E-12$ burial ground is needed to determine the extent to which nearby ditches, that convey cooling water to ponds, influence the burled solid wastes. Second, determination is needed of the extent of natural moisture movement through sediments above and below the solid waste storage zones, and the influence of this natural moisture movement on radionuclide transport. Third, semfannual ground surveys over the surface of all burial grounds is needed to determine temperature variations, zones of high concentrations of fissionable material, void spaces, the extent of organic nitrations and/or radiolys is within buried waste packages, and radionuclide uptake by plants and/or animals.

Specific recomendations and order of magnitude costs associated with these studies follow.

Evaluation of 218-E-12 Burial Ground

Problem:

The 216-B-2 ditch carries cooling water and condensate from B Plant facilities to the 216-B-3 pond. This ditch passes in an east-west direction through the center of the 218-E-12 burial ground a distance of 1000 feet and comes within 20 to 40 meters of the burial trenches. Water infiltrating into the ground along this ditch may be reaching these trenches and influencing radionuclide mobility.

Current Status:

There are no monitoring structures at this site.

Action Required:

Provide four shallow wells (23 meters deep) between the nearest approach of the 216-B-2 ditch to the trenches withtn the 218-E-12 burial garden. Neutron: surveys in these wells will indicate the extent to which the sediments are saturated near the disposal trenches.

Probable Cost (Order of Magnitude): $\$ 8,000$ (Capital)

$\frac{2,000}{\$ 10,000}$ (Expense) 
Ground Surveys of Burial Grounds

Problem:

Combustion may have taken place in burial waste packages, packages may have collapsed following burial, creating void spaces, plutonium may be concentrated in small zones within the trenches, and plants and animals may be transporting radionuclides from their stored location to the ground surface.

Current Status:

Technology and the capability to provide the data are available but the scans have not been made.

Action Required:

Infrared surveys may reveal local hot spots; gas monitors (selective for hydrogen and nitrous oxides) may reveal where radiolys is or organic nitrations might be taking place within buried waste packages. Sonic devices would be utilized for locating underground void spaces, and neutron and gamma surveys may show locations of high plutonium concentrations within ditches or in plants and animals.

Probable Cost (Order of Magnitude): $\$ 90,000$ (Expense).

Natural Moisture Movement

Problem:

Lysimeter studies indicate that in general, Hanford sediments are dry and that little or no moisure movement takes place in the zone where solid wastes are buried. There are, however, no lysimeters nor monitoring wells located specifically within the burial grounds.

\section{Current Status:}

There are however, no lysimeters nor monitoring wells specifically within the boundaries of the burial grounds for this purpose.

Action Required:

Construct a lysimeter within each of the burial grounds to permit surveillance of natural moisture movement through the sediments. Provide wells within and adjacent to the trenches in the burial to confirm that no significant radionuclide movement away from the burial trench has occurred.

Probable cost (Order of Magnitude): $\$ 500,000$ (Capital). 
Basis:

A cluster of three wells is required for each ten foot section of trench to determine concentrations of actinides. One trench would be studied in FY 1978, three trenches in FY 1979 and four trenches in FY 1980 at a cost of $\$ 50,000$ per trench. Lysimeters would provide access for determining moisture content and moisture potential as a function of depth.

\section{OPERATIUNAL NEEUS AND IMPROVEMENTS}

The currently active facilities and operating practices satisfy only the minimum requirements of containment of radioactivity and control of exposure to personnel. Improvements are needed in the areas of retrievability of TRU wastes, improved land utilization, volume reduction and protection of some operations from the effects of weather. These improvements all apply to the currently active operations and to the near term (2-3 year period). Additional facilities are also needed to handle significant quantities of new types of wastes to be generated by the Fast Flux Test facility (FFTF), scheduled to start operation in FY 1979.

Recommendations follow. The costs shown are order of magnitude; additional engineering study will be required to identify the costs more accurately.

\section{FFTF Waste Facilities}

Problem:

Extremely high activity (up to $200,000 \mathrm{R} / \mathrm{hr}$ ) solid wastes from the FFTF project are scheduled for disposal in the 200 Areas beginning FY 1979. The current disposal concept is based on placing the waste in $53 \mathrm{~cm}$ diameter $X 3.65 \mathrm{~m}$ long metal containers which will be transported in a shielding cask. Facilities must be made available for handling and disposing of approximately one container per week over a 20 year period.

\section{Current Status:}

Planning and evaluation of al ternatives has begun.

Action Required:

Develop design for:

Site facilities: rail siding, building, etc.

Facilities and equipment such as cranes or gantrys for handling the waste.

Burial facilities, caissons, etc.

Develop overall schedule for having these available when needed. 
Probable Cost (Order of Magnitude): $\$ 2,000,000$ (Expense)

$$
3,000,000 \text { (Capital) }
$$

$\$ 5,000,000$ (Total)

Improved Storage and Disposal for Caisson Waste

Problem:

The current handling of high activity wastes which are placed into caisson storage and disposal is marginal:

Waste packages are dropped into caissons. Package rupture has occurred on occasion.

Present concepts cal1 for retrieval of the entire $2.7 \mathrm{~m}$ diameter $\times 3.1$ $m$ high TRU caisson, possibiy contaminated inside, for retrieval of TRU wastes. This will be expensive and hazardous.

Individual waste packages are not retrievable from the caisson.

Wind shelter is needed for continuous operations.

\section{Current Status:}

Work has not begun.

Action Required:

Develop new concepts and designs for disposal/storage of wastes types now put into caissons which will eliminate freefall and provide for practical retrievability for TRU wastes for 20 years.

Design for land use will be considered.

Provide building(s) for adequate containment during operations.

Provide facilities for unloading, handling and disposing of TRU and nonTRU wastes.

Probably Cost (Order of Magnitude): $\$ 600,000$ (Expense) 900,000 (Capital) $\$ 1, \overline{500,000}$ (Tota7)

TRU Asphalt Pad Storage Upgrade

Problem:

The asphalt pad TRU storage facility design currently in use was developed 
as a prototype unit. It is recognized that design changes are needed to improve operability of the concept.

Action Required:

Complete studies and develop means for reducing risk of explosion or fire due to radiolytically generated hydrogen gas.

Evaluate pad storage for protection of waste packages for 20 year period.

Redesign TRU asphalt pad and TRU packaging to optimize handling, stacking, segregation of combustibles, module sampling and protection of drums from corrosion.

Provide improved waste package handling equipment and methods to increase efficiency, reduce drum damage and improve personnel safety.

Provide movable weather shelter or building of either rigid or flexible design to permit all weather operation and protect the packaged waste from weathering effects.

Probable Cost (Order of Magnitude): $\$ 400,000$ (Expense) 700,000 (Capital) $\$ 1, \overline{100,000}$ (Total)

Waste Compaction Facilities

Problem:

Compliance with ERDA Manual Chapter 0511 requires the reduction of volume of radioactive solid waste wherever practical. Large volumes of both TRU and nonTRU contaminated trash (paper, plastic, rags, laboratory gear, etc.) generated at Hanford would be compacted to reduce the land area requried and to be inc ompliance with ERDA MC 0511.

\section{Current Status:}

A prototype unit is now being designed.

Action Required:

Design facilities for sorting and compacting radioactively-contaminated wastes. Designs shall provide positive containment of radioactiveity, assay capability, and contamination-free packaging.

Identify appropriate location(s) for these facilities.

Procure and install compaction facilities. 
Probable Cost (Order of Magnitude): $\$ 1,000,000$ (Capital).

Investigate Incineration/Acid Digestion Alternatives

Problem:

ERDA MC 0511 requires the application of volume reduction techniques to radioactive wastes whenever practical. Large quantities of contaminated wastes are now on hand and continue to be generated at Hanford. Incineration or acid decomposition may be feasible for economically reducing this waste volume.

Current Status:

Hanford Engineering Development Laboratory (HEDL) is constructing a prototype acid digestion facility; cold testing to begin in FY 1977 and hot testing to begin in FY 1978. Evaluation will follow testing.

Action Required:

Investigate alternatives and determine feasibility of volume reduction of both TRU and nonTRU wastes. Incineration and acid digestion shall be compared and evaluated.

Probable Cost (Order of Magnitude): $\$ 120,000$ (Expense)

Radioactive Waste Trench Improvements

Problem:

Current methods used for trench burial of dry wastes result in an excessive use of land per unit of waste. New techniques need to be developed to improve both land and cost efficiency.

Current Status:

Work has not been started.

Action Required:

Develop improved landfill techniques and equipment to accomplish the following:

Improve land use economy.

Improve waste unloading and handling methods to increase efficiency and reduce risk of contamination release.

Develop retrieval concepts for TRU wastes in trench storage. 
Probable Cost (Order of Magnitude); $\$ 120,000$ (Expense)

Security Systems, Active TRU Storage Sites

Problem:

Active TRU storage areas are only partially fenced; they are not lighted and do not have intrusion alarm protection.

Current Status:

Design work is in progress; some of the fencing has been installed.

Action Required:

Design and install suitable security alarm system and complete the perimeter fencing.

Probable Cost (Order of Magnitude); $\$ 6,500,000$ (Capital). 